\title{
A new species of pitviper of the genus Bothrops (Serpentes: Viperidae: Crotalinae) from the Central Andes of South America
}

\author{
JUAN TIMMS ${ }^{1}$, JUAN C. CHAPARRO 2,3 , PABLO J. VENEGAS ${ }^{4}$, \\ DAVID SALAZAR-VALENZUELA ${ }^{5}$, GUSTAVO SCROCCHI ${ }^{6}$, JAIRO CUEVAS ${ }^{7}$, \\ GERARDO LEYNAUD ${ }^{8,9}$ \& PAOLA A. CARRASCO ${ }^{8,9,10}$ \\ ${ }^{1}$ Asociación Herpetológica Española, Museo Nacional de Ciencias Naturales. José Gutiérrez Abascal 2, 28006 Madrid, España. \\ ${ }^{2}$ Museo de Biodiversidad del Perú, Urbanización Mariscal Gamarra A-61, Zona 2, Cusco, Perú. \\ ${ }^{3}$ Museo de Historia Natural de la Universidad Nacional de San Antonio Abad del Cusco, Paraninfo Universitario (Plaza de Armas \\ s/n), Cusco, Perú. \\ ${ }^{4}$ División de Herpetología, Centro de Ornitología y Biodiversidad (CORBIDI), Santa Rita 10536, Of. 202, Huertos de San Antonio, \\ Surco, Lima, Perú. \\ ${ }^{5}$ Centro de Investigación de la Biodiversidad y Cambio Climático (BioCamb) e Ingeniería en Biodiversidad y Recursos Genéticos, \\ Facultad de Ciencias de Medio Ambiente, Universidad Tecnológica Indoamérica, Machala y Sabanilla, Quito, Ecuador EC170301. \\ ${ }^{6}$ UEL-CONICET and Fundación Miguel Lillo, Miguel Lillo 251, San Miguel de Tucumán, Tucumán, Argentina. \\ ${ }^{7}$ Universidad Complutense de Madrid, Av. Séneca, 2, 28040 Madrid, España. \\ ${ }^{8}$ Universidad Nacional de Córdoba, Facultad de Ciencias Exactas, Físicas y Naturales, Centro de Zoología Aplicada, Rondeau 798, \\ Córdoba 5000, Argentina. \\ ${ }^{9}$ Consejo Nacional de Investigaciones Científicas y Técnicas (CONICET), Instituto de Diversidad y Ecología Animal (IDEA), Rondeau \\ 798, Córdoba 5000, Argentina. \\ ${ }^{10}$ Corresponding author.E-mail: ammodytoides@gmail.com
}

\begin{abstract}
We describe a new species of montane pitviper of the genus Bothrops from the Cordillera Oriental of the Central Andes, distributed from southern Peru to central Bolivia. The new species can be distinguished from its congeners by the characteristic combination of a dorsal body color pattern consisting of triangular or subtriangular dark brown dorsal blotches, paired dark brown parallel occipital stripes, a conspicuous dark brown postocular stripe, the presence of canthorostrals in some specimens, prelacunal fused or partially fused with second supralabial, one scale usually separating internasals, rostral trapezoidal, two canthals oval to rounded, similar size or slightly larger than internasals, three or four medial intercanthals, eight to twelve intersupraoculars, intercanthals and intersupraoculars keeled and frequently slightly keeled, supraoculars oval, one to three suboculars, two to three postoculars, loreal subtriangular, two to six prefoveals, subfoveals absent, two or none postfoveals, one or two scales between suboculars and fourth supralabial, seven or eight supralabials, nine or eleven infralabials, 23-25 middorsal scales, 189-195 ventrals in females and 182-190 in males, 48-58 subcaudals in females and 54-63 in males, exceptionally undivided. The new species is apparently restricted to areas within Andean montane forests that are less humid and devoid of large trees.
\end{abstract}

Key words: Andes, Bolivia, morphology, Peru, phylogeny, pitviper species

\section{Introduction}

The clade Bothrops Wagler 1824 sensu lato (or "bothropoids") is a group of pitvipers that comprises 51 species distributed throughout South America (except for B. asper Garman 1884, which also extends through all Central America as far north as Mexico, and B. punctatus García 1896, which also enters the eastern side of Panama) and some islands in the Caribbean and Atlantic coast of Brazil (Campbell \& Lamar 2004; Uetz \& Hošek 2018). Based on morphological and molecular evidence, the Bothrops clade has been classified into monophyletic species groups included in two genera: the "Bothrocophias microphthalmus" Cope 1875 group (genus Bothrocophias Gutberlet \& Campbell 2001), the "Bothrops alternatus" Duméril, Bibron \& Duméril 1854 , "B. neuwiedi" Wagler 1824, "B. jararaca" Wied-Neuwied 1824, "B. jararacussu” Lacerda 1884, "B. taeniatus" Wagler 1824 and "B. atrox" Lin- 
naeus 1758 groups (genus Bothrops sensu stricto) (Fenwick et al. 2009; Carrasco et al. 2012). The species of the Bothrops clade are of medical importance due to envenoming accidents that occur across their distribution and to the pharmacological properties of their venoms; hence, they are of great interest to science and have been studied since the late 1700's (França \& Málaque 2003; Campbell \& Lamar 2004; Warrell 2004; Gutiérrez 2009; Carrasco et al. 2016).

In the past decades, several new pitviper species have been described from South America (Harvey 1994; Ferrarezzi \& Freire 2001; Silva \& Rodrigues 2008; Barbo et al. 2012, 2016; Carrasco et al. 2019), and new discoveries seem likely to occur in the Andean Mountain Range (e.g., Esqueda et al. 2005; Passos et al. 2009; Rojas-Morales 2012). This vast territory harbors large regions of poorly explored terrain with diverse habitats, most of which have favorable conditions to house pitvipers, like the deep interandean valleys (Koch et al. 2018). As many as $48 \%$ of all the pitviper species in South America are distributed at different elevations throughout the Andean range (Campbell \& Lamar 2004). In such a varied orography, where suitable habitats occur from sea level to well above $3000 \mathrm{~m}$ (e.g., Bothrops ammodytoides, B. jonathani, Carrasco et al. 2009, 2010), speciation by vicariance processes is most likely to take place.

The present study was prompted by a photograph (Fig. 1) of a specimen of Bothrops from the Bolivian Andes, found in the Refugio Los Volcanes (department of Santa Cruz), which could not be assigned to any recognized species so far. This initial photograph led to subsequent fieldwork in the area and collection of additional specimens. Concomitantly with this discovery, a systematic revision of the pitviper species present in Peru led to the identification of an undescribed species of Bothrops from the department of Puno, southeastern Peru, near the border with Bolivia. Both Bolivian and Peruvian specimens were compared and identified as the same morphotype. Morphological comparisons and phylogenetic analyses confirmed the distinctiveness and close affinity to other species of Bothrops of this population of Andean pitvipers, which we describe herein as a new species.

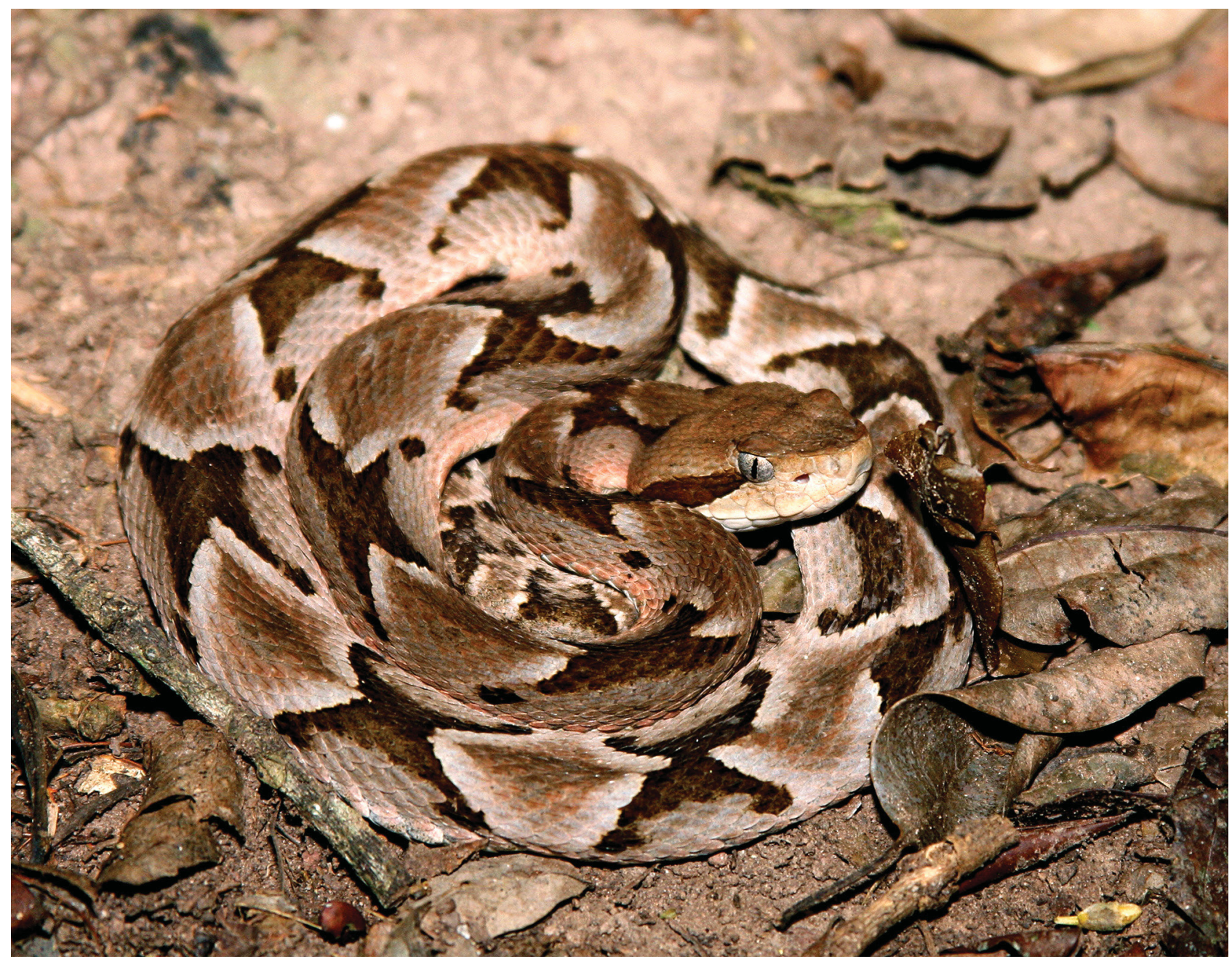

FIGURE 1. First specimen of the new species photographed in Bolivia (Refugio Los Volcanes, department of Santa Cruz). Photo by W. Guzmán. 
Specimens examined. This study was based on ten specimens of the new species, four from Bolivia and six from Peru. Two of the Bolivian specimens were found during fieldwork in Cuevas (department of Santa Cruz) on March 2017, and were preserved and deposited in the MNK (see Sabaj 2016 for this and the following institutional acronyms, excepting CZA and MUBI). Geographic coordinates for these specimens were recorded directly on the field with MotionX-GPS HD receiver using WGS84 datum. The other two specimens belong to the MNK and $\mathrm{CBF}$, respectively, and were previously catalogued as Bothrops sanctaecrucis. The Peruvian specimens belong to the CORBIDI, MUSM and MUBI (Museo de Biodiversidad del Perú, Cusco, Perú). Photographs of additional specimens observed in the field are included in Appendix 1. All photographs were deposited in the photographic collection of the MUBI. For morphological comparisons, we examined a total of 298 specimens of representative species of the Bothrops clade (see Fenwick et al. 2009; Carrasco et al. 2012): Bothrocophias microphthalmus Cope 1875, B. hyoprora Amaral 1935 and B. andianus Amaral 1923 ("B. microphthalmus" group); Bothrops ammodytoides Leybold 1873, B. alternatus Duméril, Bibron \& Duméril 1854, B. cotiara Gomes 1913, B. fonsecai Hoge \& Belluomini 1959, B. itapetiningae Boulenger 1907 and B. jonathani Harvey 1994 ("B. alternatus" group); B. diporus Cope 1862, B. erythromelas Amaral 1923, B. lutzi Miranda-Ribeiro 1915, B. marmoratus Silva \& Rodrigues 2008, B. mattogrossensis Amaral 1925, B. neuwiedi Wagler 1824, B. pauloensis Amaral 1925 and B. pubescens Cope 1870 ("B. neuwiedi" group); B. insularis Amaral 1922 and B. jararaca Wied-Neuwied 1824 ("B. jararaca" group); B. jararacussu Lacerda 1884, B. brazili Hoge 1954 and B. sanctaecrucis Hoge 1966 ("B. jararacussu" group); B. asper Garman 1884, B. atrox Linnaeus 1758, B. lanceolatus Bonnaterre 1790, B. leucurus Wagler 1824 and B. moojeni Hoge 1966 ("B. atrox" group); B. bilineatus Wied-Neuwied 1821, B. chloromelas Boulenger 1912, B. oligolepis Werner 1901, B. pulchra Peters 1862 and B. taeniatus Wagler 1824 ("B. taeniatus" group); B. pictus Tschudi 1845, B. barnetti Parker 1938, B. venezuelensis Sandner-Montilla 1952 and B. lojanus Parker 1930. The comparative material belongs to the CBF, CORBIDI, CZA (Centro de Zoología Aplicada, Córdoba, Argentina), FML, MLP, MACN, MHNC, MNK, MUBI, MUSM and MZUSP. Taxonomy follows Carrasco et al. (2012). The specimens examined for morphological comparisons are listed in Appendix 2.

Morphological study. Measurements for morphometric characters were taken with a digital caliper to the nearest $0.01 \mathrm{~mm}$. In the description, a slash (/) is used for counts from left/right sides of the body. Sex was determined by examination of the presence/absence of hemipenes. The hemipenis of one Bolivian paratype (MNK 4313) was available for examination. Definition of characters of external morphology followed Gutberlet \& Campbell (2001) and Carrasco et al. (2012), and characters of the hemipenis followed Pesantes (1989). The morphological characters recorded followed Carrasco et al. (2019).

DNA sequencing. We obtained 96\% ethanol-preserved muscle tissue samples for one specimen from Peru (CORBIDI 2067) and extracted genomic DNA using a modified salt precipitation method based on the Puregene DNA purification kit (Gentra Systems). We used PCR to amplify the cytochrome b (cytb) and NADH dehydrogenase subunit 4 (nd4) mtDNA fragments using the Gludg / AtrCB3 (Parkinson et al. 2002) and ND4 / LEU (Arévalo et al. 1994) primer pairs, respectively. We performed amplification reactions using either BioMix Red mastermix (Bioline Inc., Springfield, NJ, USA) or individual reagents (Platinum Taq DNA polymerase, dNTP mix) from Life Technologies. The $c y t b$ fragments were amplified using an initial 2.5 min denaturation cycle at $95^{\circ} \mathrm{C}$, followed by $30 \mathrm{~s}$ denaturing at $95^{\circ} \mathrm{C}, 1 \mathrm{~min}$ annealing at $45^{\circ} \mathrm{C}$ and $1.5 \mathrm{~min}$ extension at $68^{\circ} \mathrm{C}$ for 2 cycles, followed by 30s denaturing at $95^{\circ} \mathrm{C}, 30 \mathrm{~s}$ annealing at $48^{\circ} \mathrm{C}$ and $45 \mathrm{~s}$ extension at $72^{\circ} \mathrm{C}$ for 40 cycles, followed by a 15 min extension at $72^{\circ} \mathrm{C}$; $n d 4$ amplification conditions involved an initial 5 min denaturation cycle at $95^{\circ} \mathrm{C}$, followed by 30 s denaturing at $94^{\circ} \mathrm{C}, 45 \mathrm{~s}$ annealing at $52^{\circ} \mathrm{C}$ and $1 \mathrm{~min}$ extension at $72^{\circ} \mathrm{C}$ for 38 cycles, followed by a final 5 min extension at $72^{\circ} \mathrm{C}$. PCR purifications were performed using ExoSAP-IT (Affymetrix, Cleveland, OH, USA). Sequencing reactions for forward and reverse strands were conducted using the BigDye terminator cycle sequencing kit (Life Technologies) and products were sequenced by Macrogen Inc. (Seoul, South Korea). Complementary sequences were assembled and edited with CodonCode Aligner 4.

Phylogenetic analyses. In order to evaluate the systematic position of the new species we performed phylogenetic analyses of $c y t b$ and $n d 4$ sequences and morphological data. Based on Carrasco et al. (2012) and Alencar et al. (2016) we included Crotalus durissus Linnaeus 1758, Bothriechis schlegelii Berthold 1846, Lachesis muta Linnaeus 1766, Atropoides nummifer Rüppell 1845, Cerrophidion godmani Günther 1863, and Porthidium nasutum Bocourt 1868 as outgroup taxa (Appendix 2). The morphological dataset included the characters from Carrasco et 
al. (2019), with the addition of the character/data from cranial osteology used by Carrasco et al. (2012) (Appendix 3). Osteological characters were coded as missing data for the new species. The morphological matrix (Appendix 4) was then composed of 108 characters and 43 taxa, and two blocks for continuous and discrete characters, respectively. Continuous characters were analyzed without discretization, represented as ranges of two standard deviations around the mean (Goloboff et al. 2006) and standardized to the same range (0-2) to avoid scaling problems. We treated discrete characters as non-additive. The molecular dataset was composed of the sequences we obtained of the new species and sequences retrieved from GenBank for the rest of the taxa (Accession numbers in Appendix 5). The molecular matrix included two blocks, one for each gene, and had 1306 aligned sites (cytb: 642; nd4: 664). We combined the morphological and molecular matrices in a total evidence analysis, and we also performed separate analysis of the following partitions: [morphology], [continuous morphological characters], [discrete morphological characters], [cytb], [nd4], [cytb $+n d 4]$, [morphology $+c y t b],[$ morphology $+n d 4]$. The phylogenetic analyses were performed under the maximum parsimony criterion using the program TNT 1.5 (Goloboff \& Catalano 2016). Searches for optimal trees were performed using random addition sequences of Wagner trees, followed by the TBR algorithm, making 100 replications for morphology-only analyses and 500 replications for molecular-only and combined analyses, and saving up to 10 trees per replicate. All characters were analyzed under equal (EW) and implied weights (IW) (Goloboff et al. 2008). For implied weighting we used concavity values (k) between 3-10 for morphology-only analyses and 8-15 for molecular and combined-evidence analyses (Goloboff et al. 2008). Branch support was calculated under jackknifing and bootstrapping, performing 500 pseudoreplicates of 10 random addition sequences each, using a probability of elimination of 0.36 for jackknife values.

\section{Results}

Phylogenetic analyses confirmed that the new species is indeed a member of the genus Bothrops (Figs. 2-4). The analyses of total evidence, under both EW and IW, recovered the same single topology in which the new species is basal to a clade conformed by the "B. neuwiedi" and "B.jararaca" species groups, with medium-low support values (Fig. 2). However, the results of the different partitioned analyses differed among them, as shown in Table 1. Some of these alternative analyses recovered the same position for the new species as in the total evidence analyses, with medium-high support values (e.g., cytb $+n d 4$; Fig. 3). However, the phylogenetic signal of the morphological data (Fig. 4) and part of the molecular evidence (see $n d 4$ under EW in Table 1) indicate a closer relationship of the new species to the "Bothrops jararacussu" group, mostly as the sister taxa of B. sanctaecrucis, with medium-low support values. The relation of the new species with the "Bothrops neuwiedi" + "B. jararaca" clade in total evidence analyses is supported by nine molecular characters and no morphological synapomorphies. Its relationship with the "Bothrops jararacussu" clade, as in the morphology-only analysis, is supported by four morphological characters $\left(\mathrm{n}^{\mathrm{o}}\right.$ of supralabials, $\mathrm{n}^{\mathrm{o}}$ of anterior intercanthals, caudal spine length/tail length, and presence of a swollen dorsal area in the intralobular area of the hemipenial lobes). The phylogenetic position of the new species within the genus is thus not fully resolved. However, the different positions of the new species shown by these preliminary phylogenetic analyses highlight the distinctiveness of this Andean population as a new species, which we describe below.

\section{Bothrops monsignifer sp. nov.}

Figures 1, 5-12, Table 3

Bothrops andianus, not Amaral 1923, Campbell \& Lamar 2004 (Fig. 126, not text).

Bothrops mattogrossensis, not Amaral 1925, Campbell \& Lamar 2004 (Plate 645, not text).

Bothrops sanctaecrucis, not Hoge 1966, Miranda Calle \& Aguilar-Kirigin 2011, part.

Holotype. An adult female (MNK 5556; Figs. 5A, 7A, 8B, F) collected by local people on March 11, 2017 at $13 \mathrm{~km}$ southwest to Refugio Los Volcanes (18 $11^{\circ} 51.10^{\prime \prime} \mathrm{S}, 63^{\circ} 40^{\prime} 5.95^{\prime \prime} \mathrm{W} ; 1658 \mathrm{~m}$ above sea level, asl hereafter), Cuevas Ecological Center, province of Florida, department of Santa Cruz, Bolivia. The specimen was legated to MNK by J. Timms.

Paratypes. Nine specimens. Subadult female (MNK 5557; Fig. 5B, 7B) collected by J. Timms on March 22, 2017 at El Palmar, (18¹1'46.19"S, 63040'1.82"W, 1629 m asl), Cuevas Ecological Center, province of Florida, 


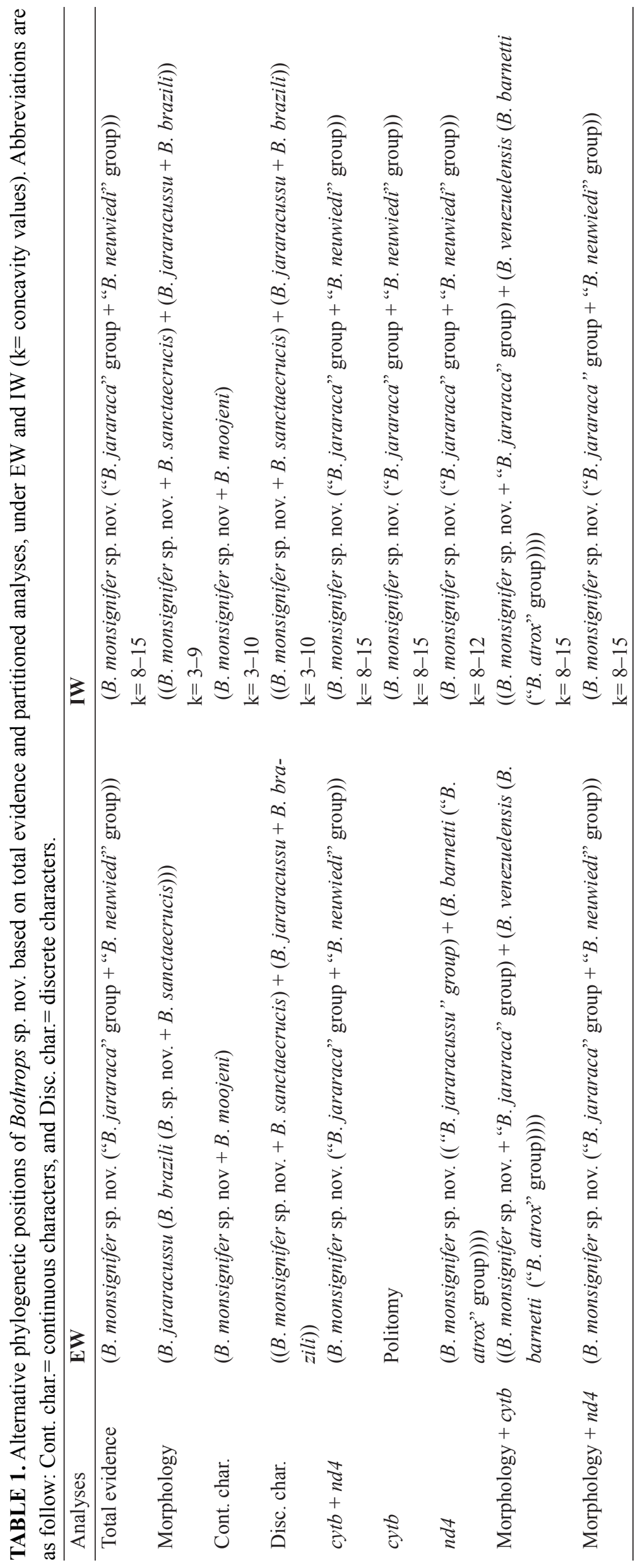


department of Santa Cruz, Bolivia; adult male (MNK 4313) collected by H. Fernández and M. Amaya on April 22, 2007 at Laguna Volcan (18 $7^{\circ} 19.9^{\prime \prime} \mathrm{S}, 63^{\circ} 38^{\prime} 57.8^{\prime \prime} \mathrm{W} ; 1120 \mathrm{~m}$ asl), province of Florida, department of Santa Cruz, Bolivia; adult female (CBF 3359) collected by A. Apaza, date unknown, at Bajo Hornuni (16 $12^{\prime} 54.4^{\prime \prime S}$, 67053'09.8"W; 1935 m asl), Cotapata National Park, province of Nor Yungas, department of La Paz, Bolivia; adult female (CORBIDI 10377; Figs. 5C, 6A, 7C, 8C) collected by local people on January 5, 2007 at San Juan del Oro (14'16'56.11"S, 69¹3'14.71"W; 1993 m asl), district of Yanahuaya, province of Sandia, department of Puno, Peru; two juvenile males (CORBIDI 2058, 2067; Figs. 5E-F, 6B-C, 7F, 8A), offspring of CORBIDI 10377, born in captivity on February 3, 2007; subadult female (MUBI 5675; Figs. 7D, 8D-E) collected by J.C. Chaparro and A.J. Quiroz on November 15, 2006 at Pacopacuni (13'52'29.7"S, 6940'05.4"W; $898 \mathrm{~m}$ asl), province of Sandia, department of Puno, Peru; subadult male (MUBI 5677; Figs. 7E) collected by J.C. Chaparro and A.J. Quiroz on November 16, 2006 at Chuine (14' $1^{\prime} 9.20^{\prime \prime} \mathrm{S}, 6^{\circ} 43^{\prime} 35.20^{\prime \prime} \mathrm{W} ; 1500 \mathrm{~m}$ asl), province of Carabaya, department of Puno, Peru; subadult female (MUSM 25600; Figs. 5D, 6D) collected by D. Rodríguez on September 30, 2006 at San Gabán $\left(13^{\circ} 32^{\prime} 55.77^{\prime \prime S}, 70^{\circ} 26^{\prime} 24.69^{\prime \prime W} ; 891 \mathrm{~m}\right.$ asl), province of Carabaya, department of Puno, Peru.

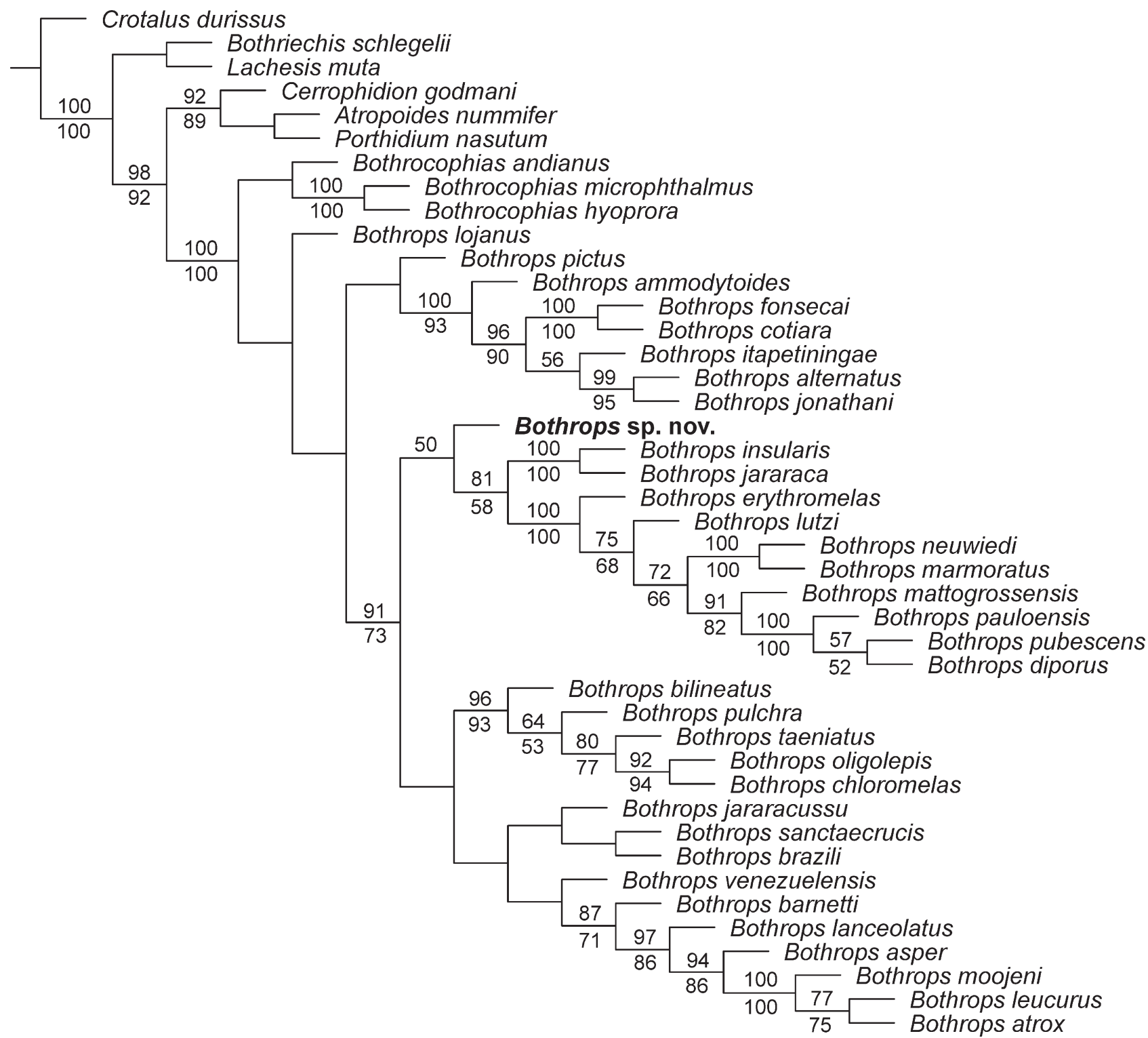

FIGURE 2. Single cladogram obtained in the analysis of total evidence under equal weights (length=3263.873). Jackknife and bootstrap values ( $>50 \%$ ) shown above and below nodes, respectively.

Diagnosis: Bothrops monsignifer may be distinguished from its congeners by the unique combination of the following morphological features: canthorostrals, a feature absent in the rest of Bothrops, present in some specimens; prelacunal fused or partially fused with $2^{\text {nd }}$ supralabial; internasals $1 / 1$, sometimes separated by one scale; 
rostral trapezoidal; canthals $1 / 1$, oval to rounded, with similar size or slightly larger than internasals; medial intercanthals 3-4; intersupraoculars 8-12; intercanthals and intersupraoculars keeled and frequently slightly keeled; supraoculars oval; suboculars 1-3; postoculars 2-3; loreal subtriangular; prefoveals 2-6; subfoveals absent; postfoveals $0-2$; scales between suboculars and $4^{\text {th }}$ supralabial $1-2$; supralabials $7-8$; infralabials $9-11$; middorsal scales 23-25; ventrals in females 189-195, in males 182-190; subcaudals in females 48-58, in males 54-63; subcaudals divided, exceptionally some of them entire; dorsal blotches triangular or subtriangular dark brown, usually fused on the vertebral line; additional markings between the blotches absent or faint in females, present and conspicuous in males; conspicuous and dark postocular stripe, 2.5-3.0 scales width, starting posteriorly to the eye, encroaching $2-3$ supralabials and one infralabial, not bordered dorsally by a pale band (a feature displayed by many bothropoid species).

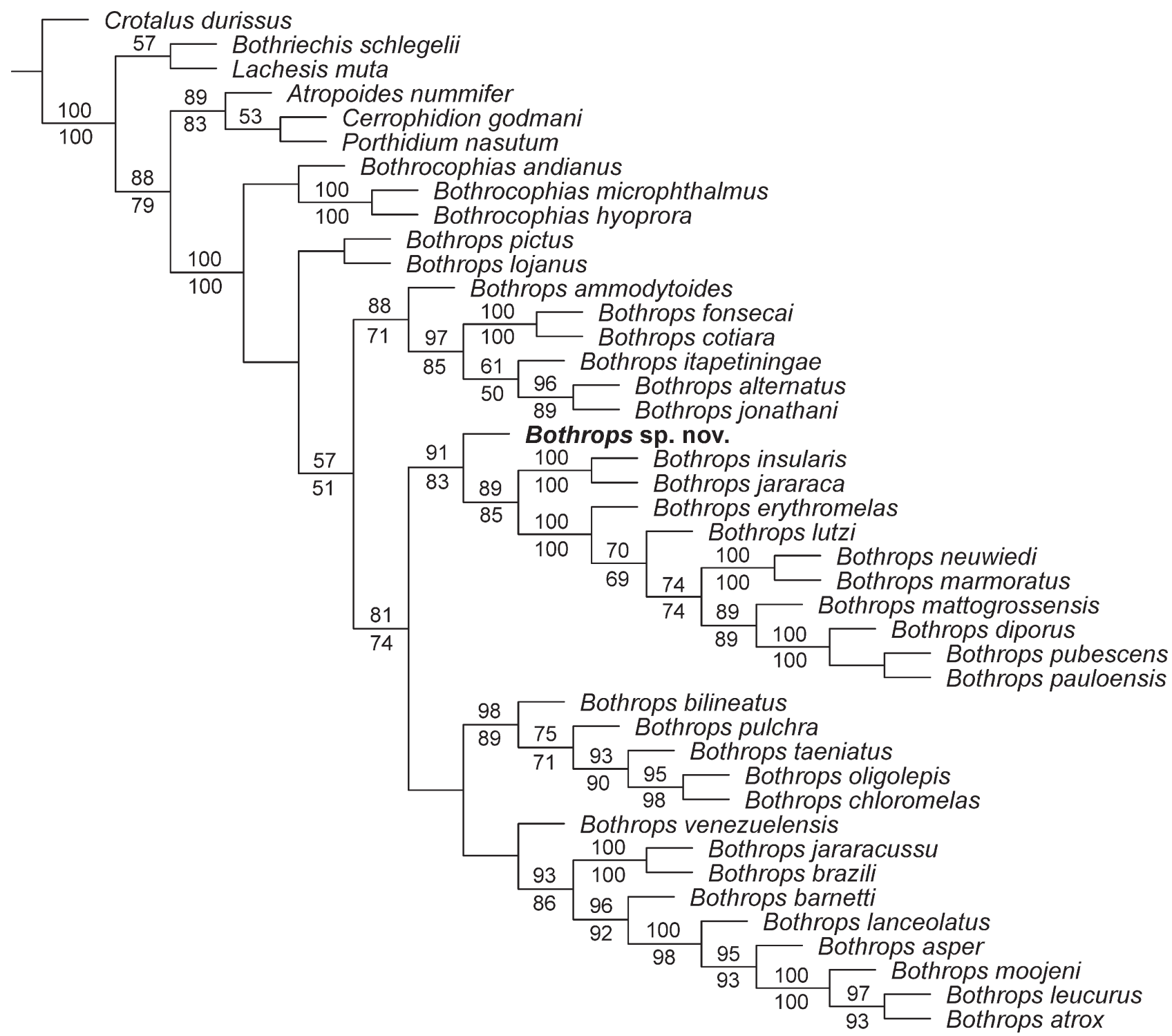

FIGURE 3. Single cladogram obtained in the analysis of $c y t b$ and $n d 4$ partitions under implied weights $(\mathrm{k}=15$; length $=2855$; fit $=620.765)$. Jackknife and bootstrap values $(>50 \%)$ shown above and below nodes, respectively.

Comparisons (conditions for other species in parentheses) (Fig. 9). Bothrops monsignifer is easily distinguished from the species of Bothrocophias by the pattern of subtriangular and conspicuous dorsolateral blotches along the body (vs. crossbands irregularly outlined), the absence of upturned snout (vs. presence) and the absence of tuberculate keels in body scales (vs. presence). However, Bothrops monsignifer is similar to Bothrocophias microphthalmus and B. hyoprora by the presence of canthorostrals, tiny scales located between the rostral, nasal, internasal and/or canthal (Fig. 8D). Although not present in all the specimens of Bothrops monsignifer, these unusual scales distinguish the new species from its congeners, as they were not observed in any other species of Bothrops. 


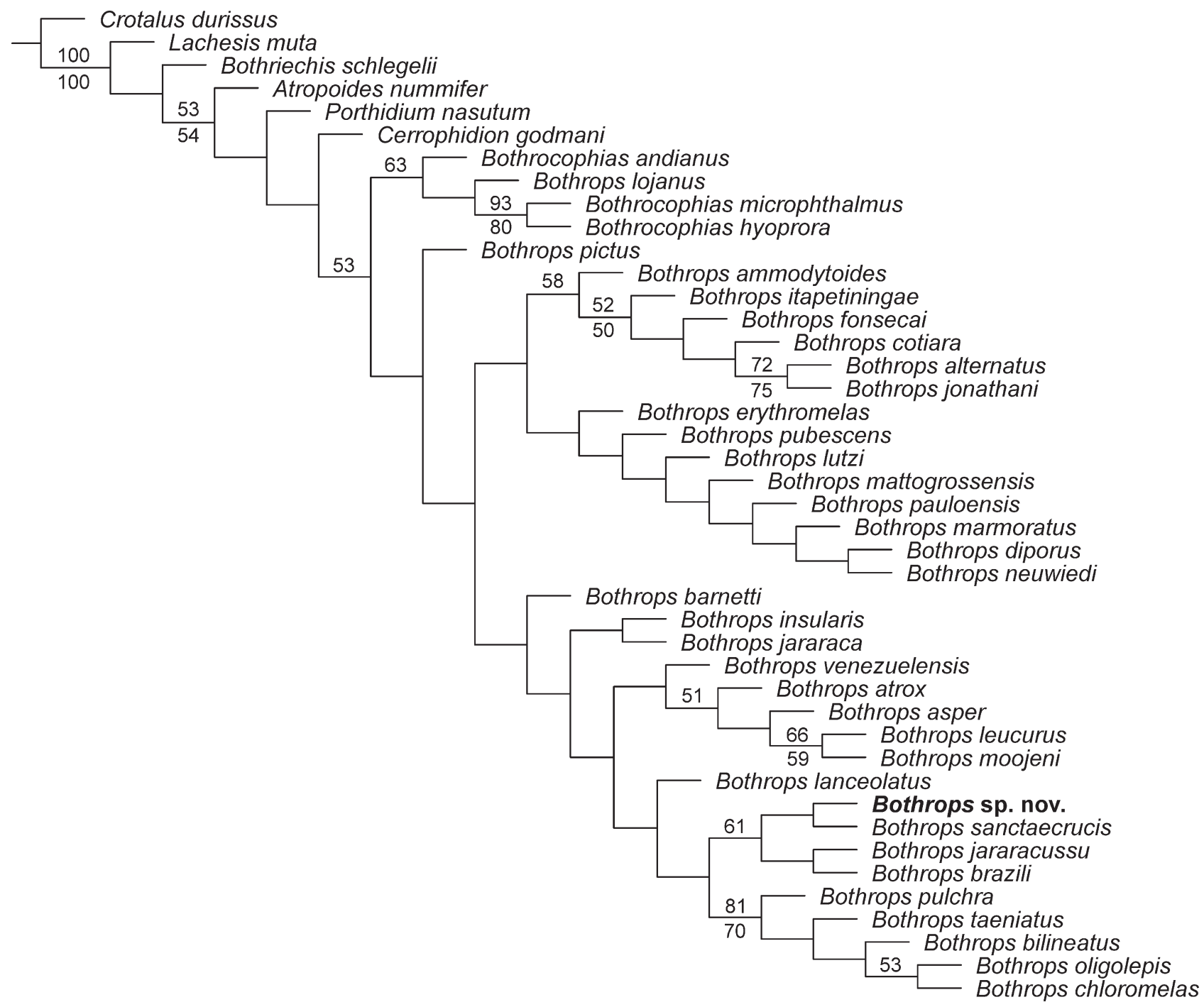

FIGURE 4. Single cladogram obtained in the analysis of morphology under implied weights $(k=9$; length $=384.608$; Fit $=$ 80.087). Jackknife and bootstrap values ( $>50 \%$ ) shown above and below nodes, respectively.

Bothrops monsignifer is easily distinguished from the species of the "B. alternatus" and " $B$. neuwiedi" groups by the condition of the prelacunal scale fused with $2^{\text {nd }}$ supralabial (Figs. 8B-D) (vs. not fused), and the absence of subfoveals (vs. presence). They are also distinguished by the pattern of subtriangular and conspicuous dorsolateral blotches on the body (vs. C-shaped or rectangular in "Bothrops alternatus" and trapezoidal in "B. neuwiedi"). Some immature males of Bothrops monsignifer may be confused with B. mattogrossensis (geographically close member of " $B$. neuwiedi"), because of their dark spots between dorsolateral blotches and labial scales (which tend to fade in adult males), features present in B. mattogrossensis.

The new species is distinguished from species of the "Bothrops atrox" and "B. jararaca" groups by the oval to rounded canthals (Figs. 8E-F) (vs. elongated). It can be distinguished from Bothrops atrox (a geographically close member of the " $B$. atrox" group) by its pattern of subtriangular and conspicuous dorsolateral blotches (vs. trapezoidal with diffuse and pale edges), the presence of white bands over a dark ground color on the tail (vs. absence) and the ventral speckling (vs. ventral checkerboard pattern). Bothrops monsignifer can be easily distinguished from the species of the "B. taeniatus" group by the pattern of dorsolateral subtriangular body blotches (vs. banded) and the absence of black-greenish or brown-greenish coloration (vs. presence).

Bothrops monsignifer is similar to species of the "B. atrox", "B. jararaca", "B. jararacussu", and "B. taeniatus" groups in the presence of a lacunolabial (i.e. prelacunal fused with $2^{\text {nd }}$ supralabial) and the absence of subfoveals. They also share the general shape of supralabials, which are bigger in size than those of species of the "Bothrops alternatus" and "B. neuwiedi" groups. The new species is most similar to Bothrops sanctaecrucis and B. brazili, 
geographically close species of the "B. jararacussu" group. They resemble each other in having oval to rounded internasals and canthals, and dark, conspicuous, triangular or subtriangular dorsolateral blotches. The absence of additional markings between dorsolateral blotches has only been observed in Bothrops muriciencis (a member of " $B$. jararacussu", endemic to northeastern Brazil). Bothrops monsignifer can be distinguished from B. brazili by numbers of ventrals, prefoveals, medial intercanthals and gulars (Table 2), larger dorsolateral blotches, and broad dark brown postocular stripe (vs. thin light brown or gray). It can be distinguished from Bothrops sanctaecrucis by numbers of ventrals, prefoveals, medial intercanthals, gulars and intersupraoculars (Table 2), and by the relative size of canthals (small vs. large). The new species may be confused with Bothrops sanctaecrucis given their similar pattern of body coloration, but they are easily distinguished by the condition of the postocular stripe, which is conspicuous and wide in B. monsignifer and faint or absent in B. sanctaecrucis. We refer to Table 2 for additional comparisons between Bothrops monsignifer and geographically close species of Bothrocophias and Bothrops.
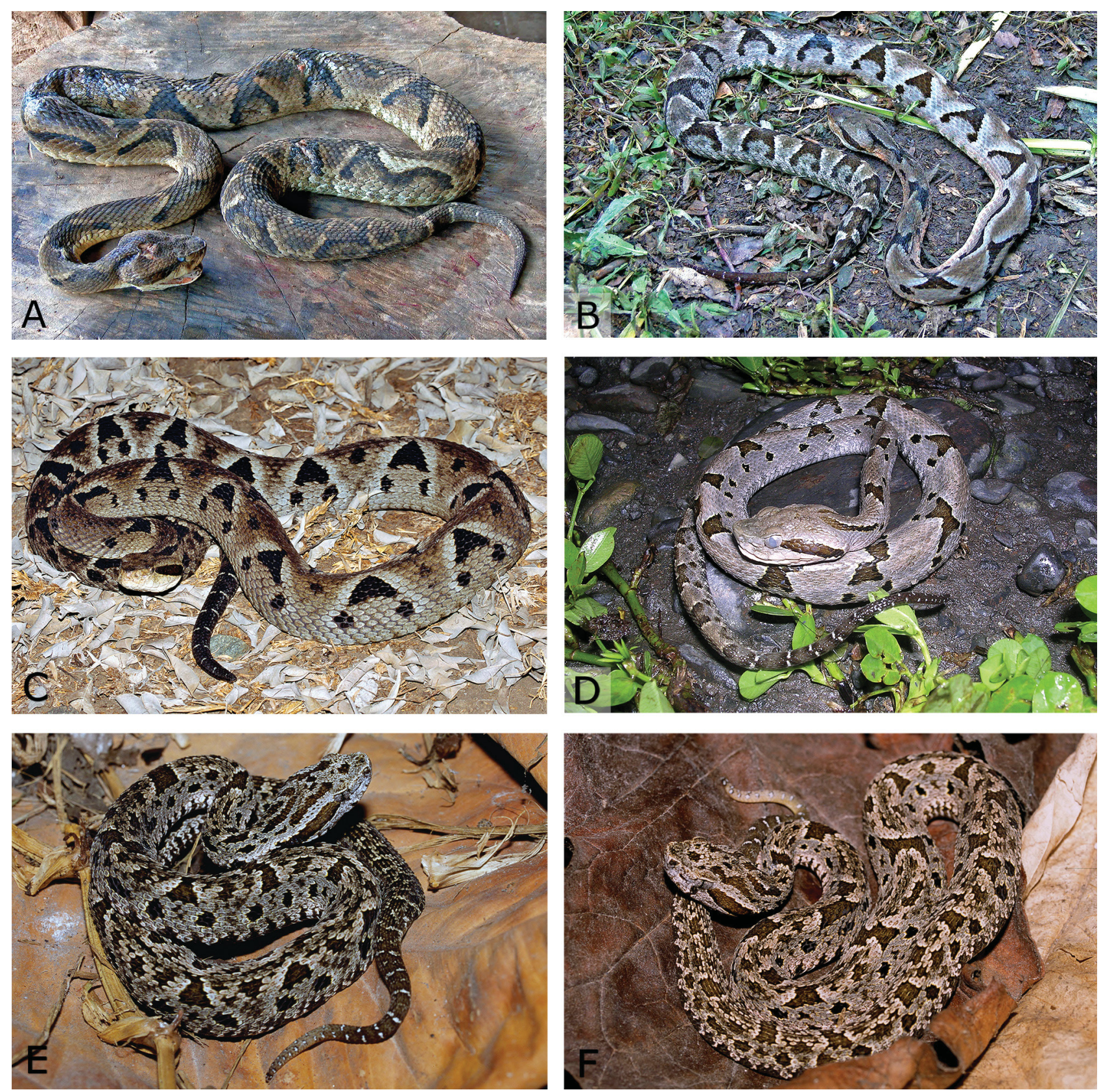

FIGURE 5. General view of the holotype (MNK 5556-A, TL= $1280 \mathrm{~mm})$ and paratypes $(\mathrm{MNK} 5557-\mathrm{B}, \mathrm{TL}=865 \mathrm{~mm}$; CORBIDI $10377-\mathrm{C}, \mathrm{TL}=1178 \mathrm{~mm}$; MUSM 25600-D, TL= $355 \mathrm{~mm}$; CORBIDI 2067—E, TL= $448 \mathrm{~mm}$; CORBIDI 2058$\mathrm{F}, \mathrm{TL}=299 \mathrm{~mm}$ ) of Bothrops monsignifer. Photos by J. Timms (A, B), M. Lundberg (C, E, F), and D. Rodríguez (D). TL= total length. 


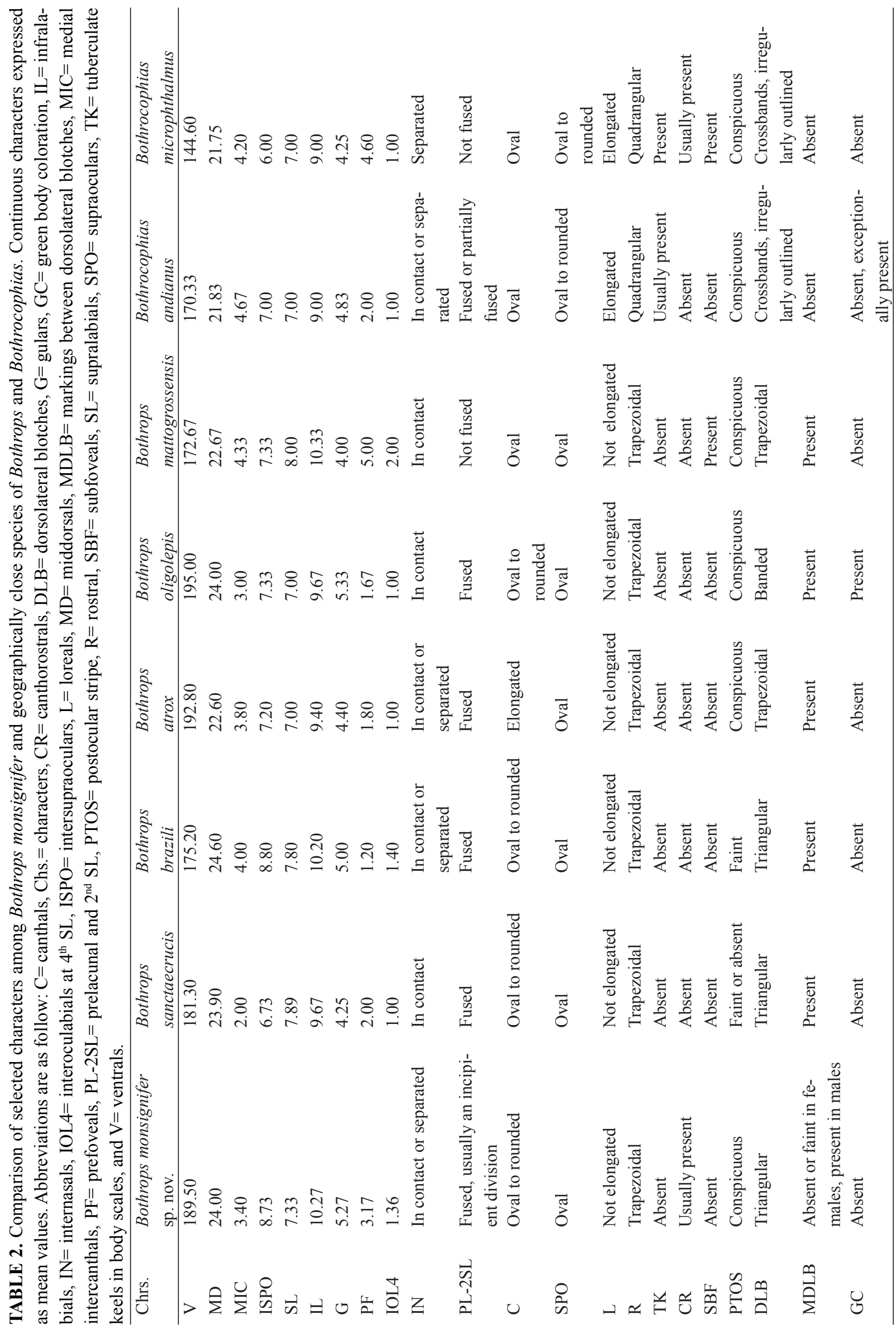



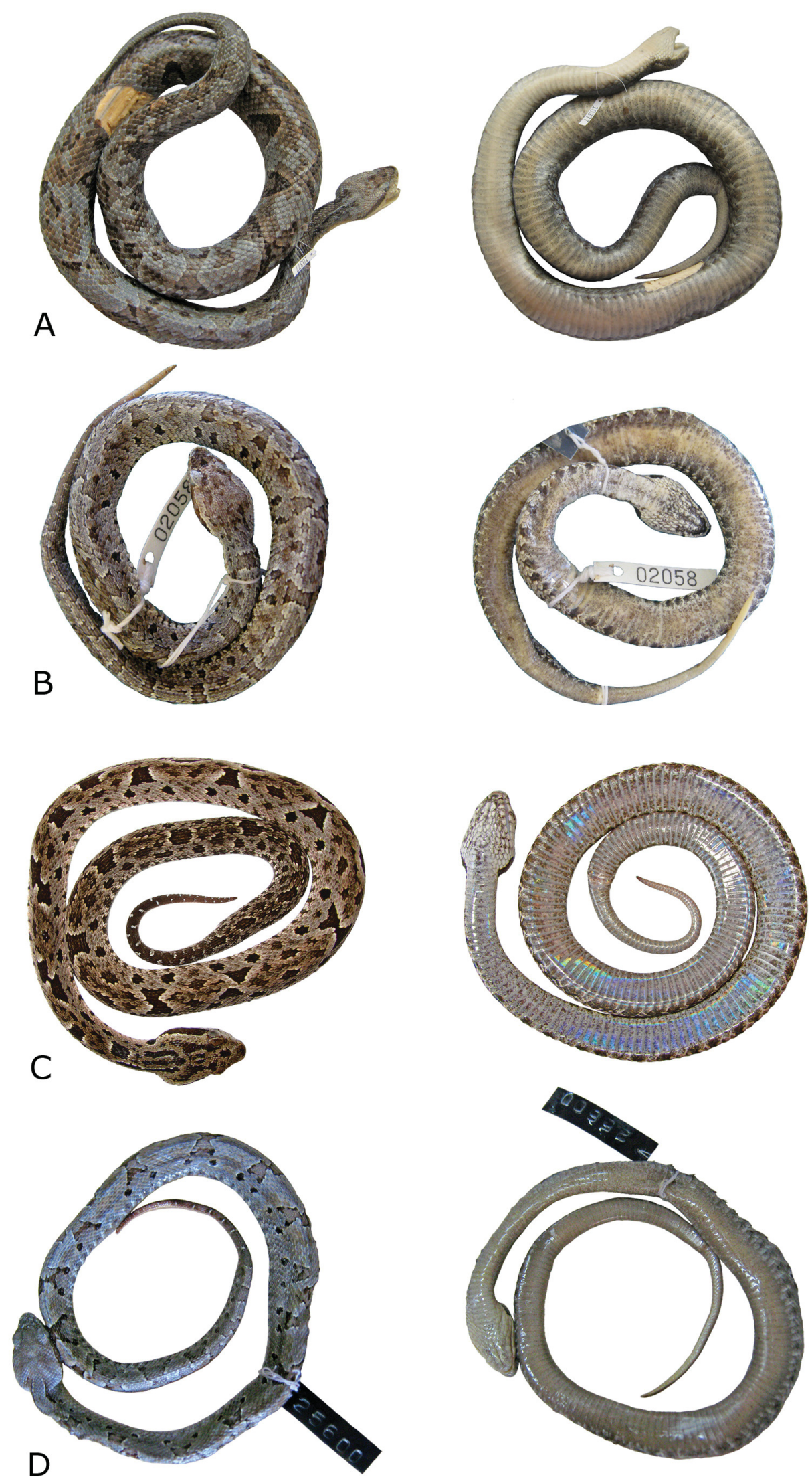

FIGURE 6. Dorsal (left) and ventral (right) views of preserved paratypes (CORBIDI 10377-A, TL=1178 mm; CORBIDI 2058-B, TL= $299 \mathrm{~mm}$; CORBIDI 2067-C, TL= $448 \mathrm{~mm}$; MUSM 25600-D, TL= $355 \mathrm{~mm}$ ) of Bothrops monsignifer. TL= total length. 


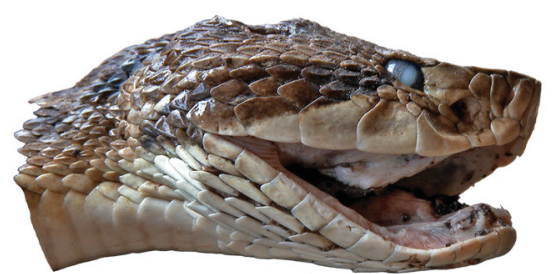

A

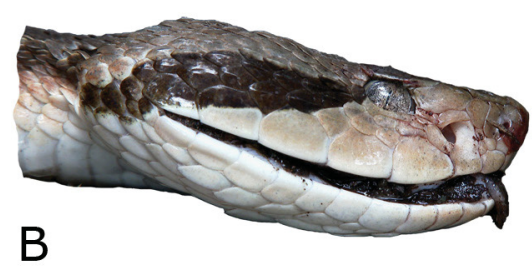

B

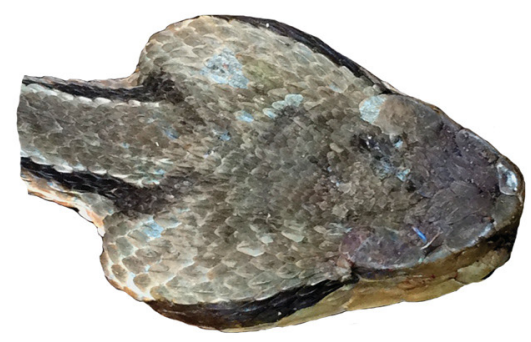

C
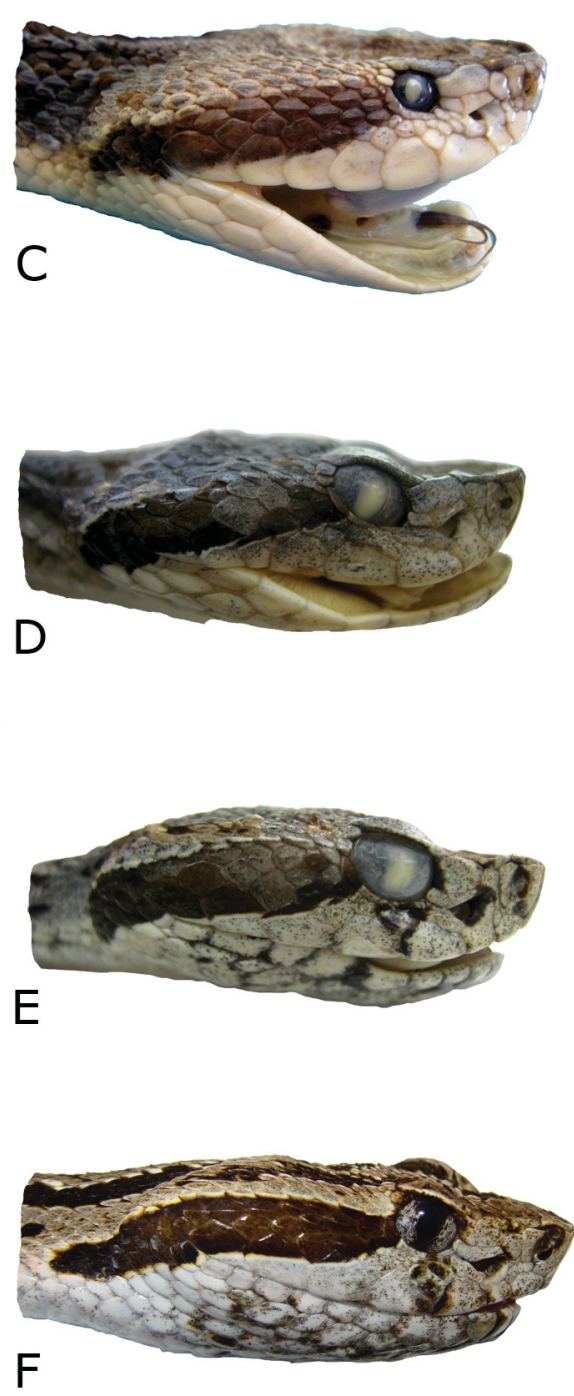
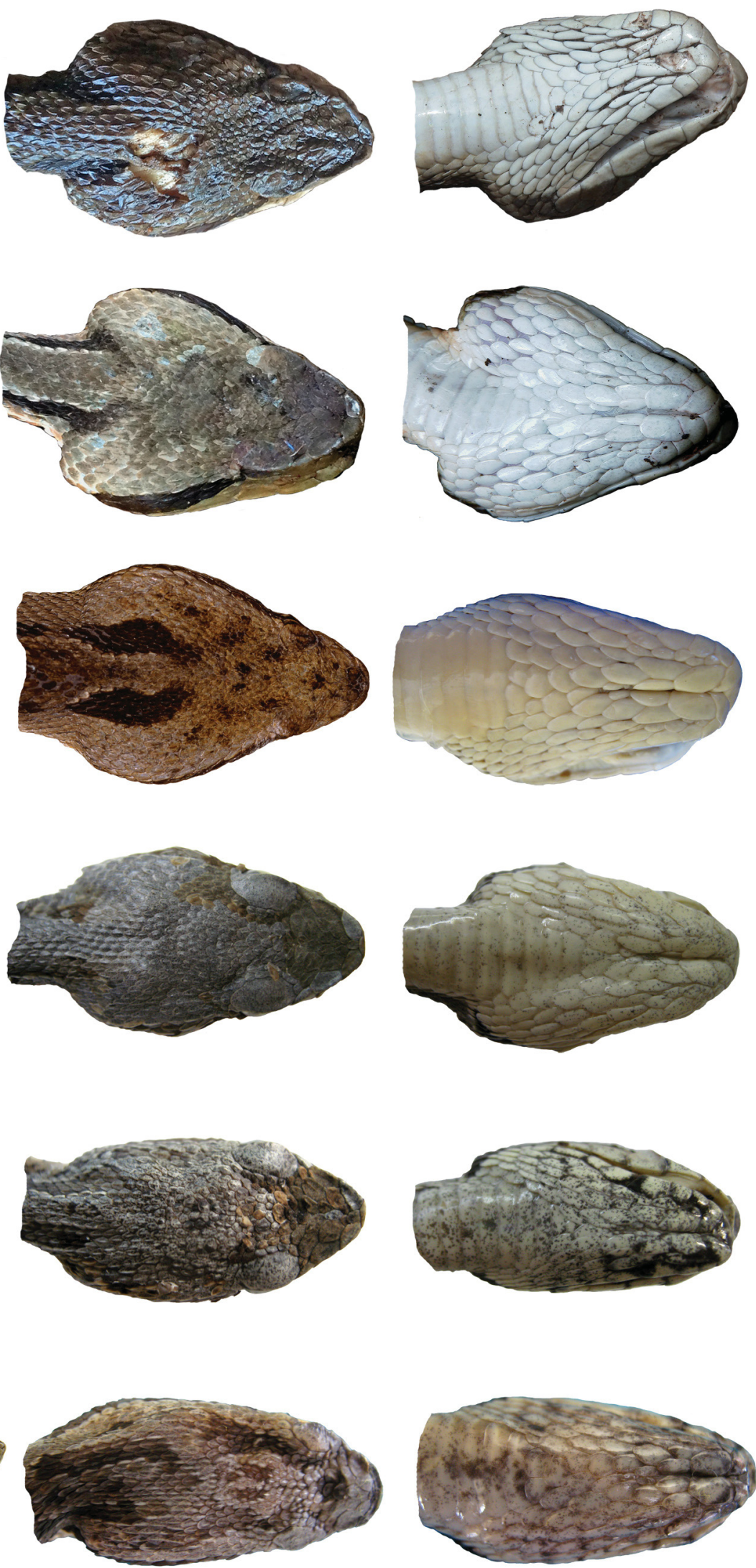

FIGURE 7. Lateral, dorsal and ventral views of the head of preserved holotype (MNK 5556-A, HL=53 mm) and paratypes (MNK 5557—B, HL= $38 \mathrm{~mm}$; CORBIDI 10377-C, HL= $51 \mathrm{~mm}$; MUBI 5675-D, HL= $21 \mathrm{~mm}$; MUBI 5677-E, HL=21 $\mathrm{mm}$; CORBIDI 2067-F, HL=25 mm) of Bothrops monsignifer. $\mathrm{HL}=$ head length. 

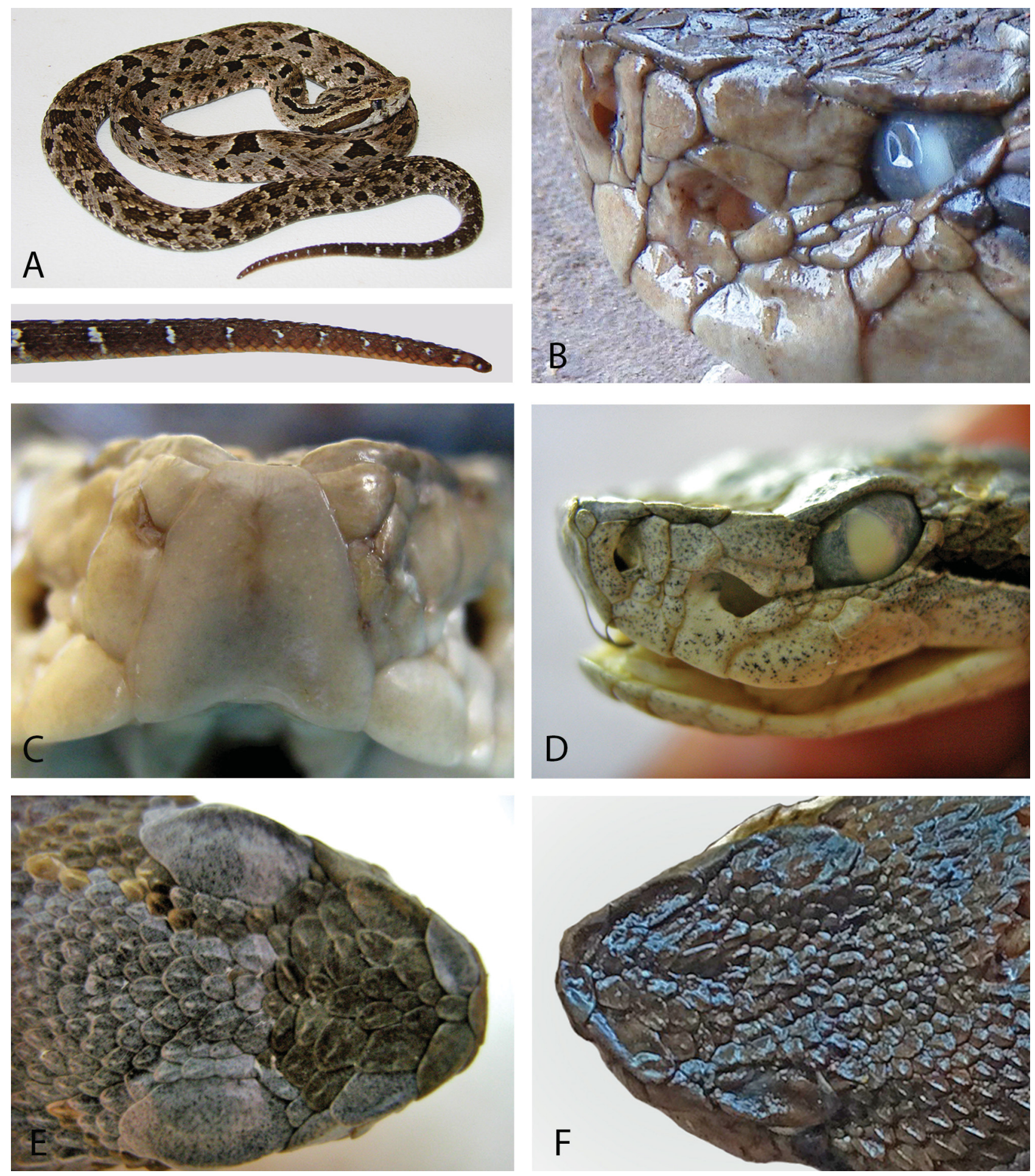

FIGURE 8. General view in life of the paratype (CORBIDI 2067-A, TL=448 mm) of Bothrops monsignifer showing detail of tail coloration. Anterior-lateral view of the head of preserved holotype (MNK 5556-B, HL= $53 \mathrm{~mm}$ ) of Bothrops monsignifer showing partially fused lacunolabial. Frontal view of the head of paratype (CORBIDI $10377-\mathrm{C}, \mathrm{HL}=51 \mathrm{~mm}$ ) of Bothrops monsignifer showing the rostral scale. Lateral view of the head of paratype (MUBI $5675-\mathrm{D}, \mathrm{HL}=21 \mathrm{~mm}$ ) of Bothrops monsignifer showing canthorostral. Anterior-dorsal view of the head of paratype (MUBI 5675-E; HL=21mm) of Bothrops monsignifer showing separated internasals. Anterior-dorsal view of the head of holotype (MNK 5556-F, HL=53 mm) of Bothrops monsignifer showing internasals in contact. 

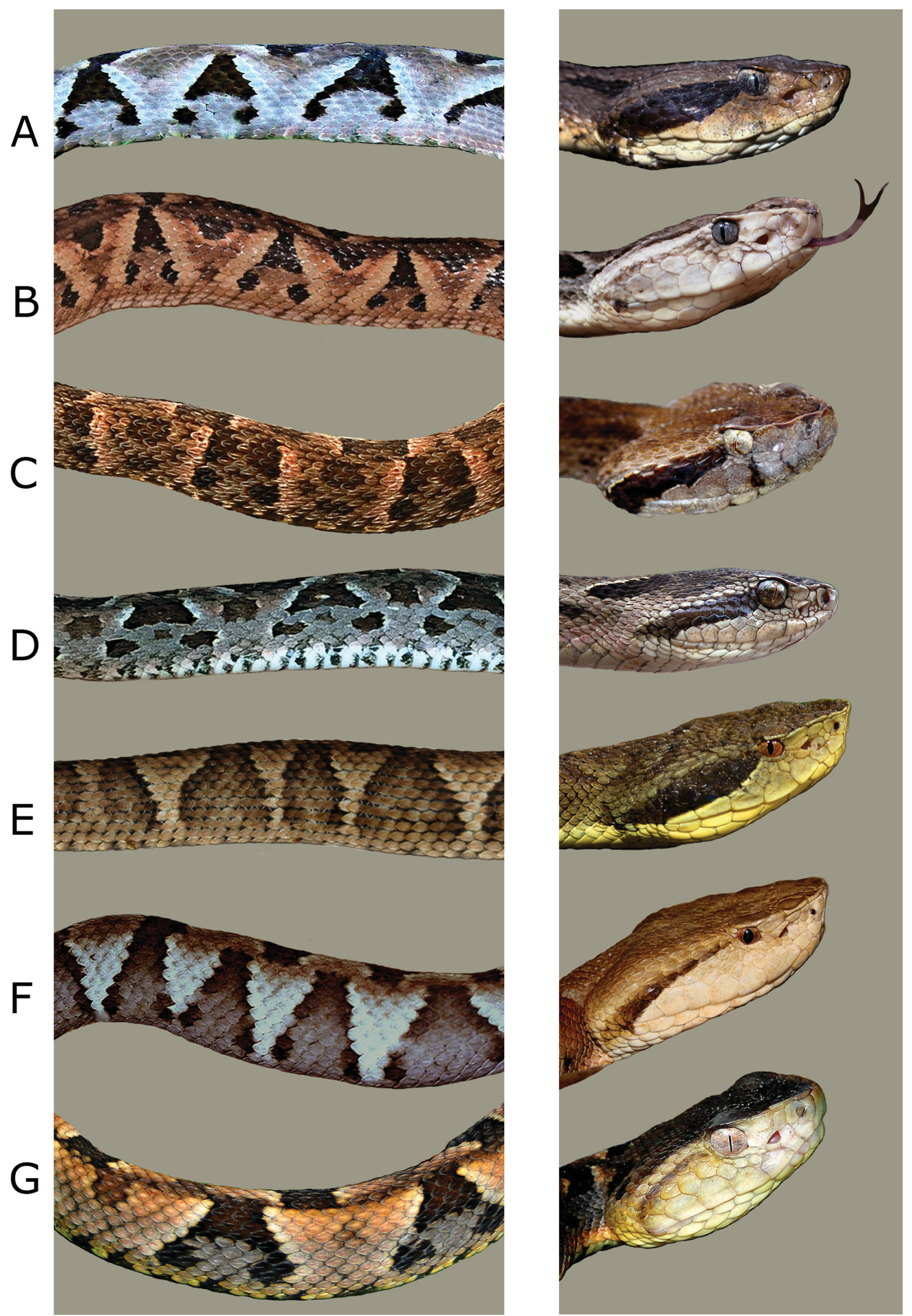

FIGURE 9. Dorsolateral views of the body and head of Bothrops monsignifer (A), Bothrops sanctaecrucis (B), Bothrops atrox (C), Bothrops mattogrossensis (D), Bothrocophias andianus (E), Bothrocophias microphthalmus (F), and Bothrops brazili (G). Photos by J. Timms (A/body, B/head, C/body, D/head, E/body), P. Venegas (F/body/head, G/body/head), J. Cuevas (A/head, D/body, E/head), M. Candel (C/head) and P. Gómez (B/body). 
Description of the holotype. Total length $1280 \mathrm{~mm}$; tail length $152 \mathrm{~mm}$; rostral trapezoidal; canthus rostralis sharp; internasals oval, in contact; canthals $1 / 1$, oval and slightly larger than internasals; intercanthals anterior 3 , medial 4, and posterior 6; intersupraoculars 9; intercanthals and intersupraoculars slightly keeled; supraocular oval; postoculars $3 / 2$; suboculars $1 / 2$, elongated; preoculars $3 / 3$; upper preocular contributing to canthus rostralis; lower preocular not contacting orbit; loreal subtriangular, taller than wide; prefoveals $2 / 2$; subfoveals absent; postfoveals $2 / 2$; prelacunals partially fused/fused with $2^{\text {nd }}$ supralabial; one scale between the suboculars and $4^{\text {th }}$ supralabial; supralabials $7 / 7$; infralabials 11/11, first pair contacting medially; six gulars between chinshields and first ventral; dorsals at midbody 23; ventrals 194; subcaudals 50, all divided; paraventrals slightly keeled.

In life, dorsum of head uniformly brown, with a pair of dark brown parietal blotches, and two dark brown parallel occipital stripes that cover back of head and nape; postocular stripe uniformly dark brown; postocular stripe starts behind the eye, progressively widens, covering partly the last three supralabials, and ending behind the rictus; dorsal ground color of body pale brown to cinnamon. Each side of the body bears 18-20 subtriangular, capital A-shaped, dorsolateral blotches, which are dark brown and bordered in white. Some dorsolateral blotches are fused along the vertebral line; ventral surface of body finely speckled, speckling more conspicuous laterally; tail dark brown with white bands and distal half of the ventral surface pale orange; iris salmon-gray; tongue pinkish-brown.

After preservation in formalin and maintenance in ethanol 70\%, ground color of head and body grayish-brown; dorsolateral blotches brown to dark gray, bordered with white; postocular stripe dark brown; parietal blotches tend to fade, but parallel dark gray stripes on the back of head mostly visible; orange pigment on the distal half of tail fades after preservation.

Intraspecific variation. Variation in measurements and scalation among the specimens of Bothrops monsignifer is summarized in Table 3. All specimens of the new species display divided subcaudals, except for one (CORBIDI 2058), in which 10 of 63 subcaudals are undivided, a rare condition within Bothrops. Coloration of head and body is sexually dimorphic: supralabials, infralabials and gulars are immaculate or slightly speckled in females while they are mottled in males, including conspicuous markings between $3^{\text {rd }}-4^{\text {th }}$ supralabials in immature males; dorsolateral blotches in females are mostly not fragmented, some of the blotches of the same side of the females are fused together forming double elongated markings; in males, dorsolateral blotches are mostly fragmented in a trapezoidal upper portion and a pair of rounded inferior blotches, and no lateral blotches are fused; additional markings between dorsolateral blotches are absent or faint in females, and are present in males, being more conspicuous in immature males; in females, the anterior portion of the ventral surface of body is almost immaculate, while in males it is slightly to strongly speckled. Peruvian and Bolivian specimens of Bothrops monsignifer show geographic variation in one character of head scalation: all Peruvian specimens present a small scale separating the internasals, while this scale is lacking in Bolivian specimens (Figs. 8E-F).

Hemipenial morphology (Fig. 10). Organ strongly bilobed; hemipenial lobes fusiform and parallel, comprising $70 \%$ of total hemipenial length; hemipenial body $30 \%$ of total hemipenial length; capitulum longer on sulcate (ventral) side, occupying 65\% of each lobe; capitulum covered by spinulated calyces; hook-shaped spines distributed symmetrically on the lobes; smaller, curved spines present on the intralobular region, located distally at lobes; hemipenial lobes with swollen intralobular areas; hemipenial body covered by spinules; microornamentation on the intrasulcar region absent; sulcus spermaticus bifurcating at half-length of hemipenial body.

The general structure of the hemipenis of the new species is similar to that found in Bothrops sanctaecrucis, $B$. brazili, and B. jararacussu; and the presence of a swollen intralobular area in the hemipenial lobes is apparently a synapomorphy of the group. However, while the new species and $B$. sanctaecrucis display hook-shaped spines on the lobes, these spines are slender and curved in B. brazili and B. jararacussu.

Distribution and natural history (Figs. 11-12). Bothrops monsignifer is a montane species distributed along the Cordillera Oriental in the Central Andes, from southern Peru to central Bolivia. In Bolivia, it is known from the departments of Santa Cruz, Cochabamba and La Paz. In Peru, it is known only from four localities at the department of Puno, in the humid montane forest (Yunga ecoregion, according to Brack 1986) of the Cordillera de Carabaya, in the upper Inambari and Tambopata basins. The Cordillera de Carabaya represents a mountain range that extends in a northwest-southeast direction, and constitutes a northern limit for the Altiplano Plateau (Kontak et al. 1990); it continues in a southeasterly direction in a series of mountain ranges that conform the Cordillera Oriental in northwestern-central Bolivia. The type locality of Bothrops monsignifer (area of Refugio Los Volcanes) is located in the "Elbow of the Andes", an area where the Andean Range turns south. This is a transitional area where the Southern Andean Yungas (Tucuman-Bolivian forest) replaces the Bolivian Yungas, and different ecoregions are represented, 


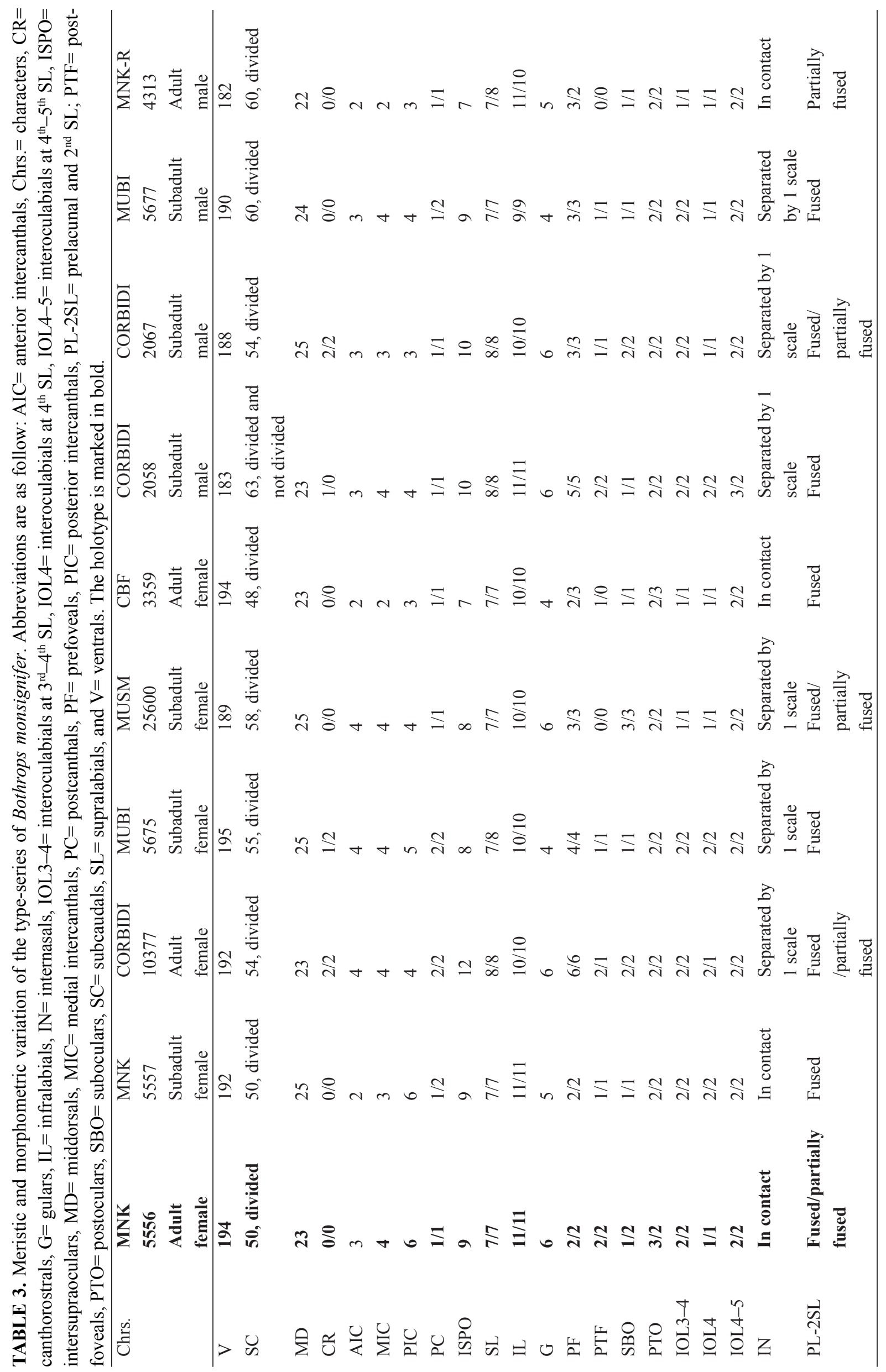


from Amazonian and Andean forests to open forests of the Chaco and Cerrado (Mueller et al. 2002; Harvey \& Muñoz 2004; Perger \& Guerra 2012).

Bothrops monsignifer seems to be restricted to montane forests on the eastern slopes of the Andean Mountain Range, at 890-2133 m. Apparently it is restricted to specific conditions within montane forests, which makes it a rare species and quite difficult to find. In the area of Refugio Los Volcanes (Bolivia), four individuals, including the holotype and one paratype, were found in a period of three weeks. During that time, as many as twelve individuals of Bothrocophias andianus were observed in the same area. Although Bothrocophias andianus and Bothrops monsignifer are sympatric, they seem to occupy different ecological niches. The new species seems to prefer areas devoid of large trees, which are slightly less humid and more exposed to sunlight, whereas Bothrocophias andianus is only found in very humid, dark and overgrown forest. In the locality of San Juan del Oro, Sandia Province (Peru), Bothrops monsignifer is sympatric with Crotalus durissus (Remuzgo et al. 2000). The distribution of Bothrops monsignifer and B. sanctaecrucis is apparently disjunct, with B. sanctaecrucis inhabiting lower altitudes than the new species (altitudinal records of specimens examined in this study range between 210-380 m). Miranda Calle \& Aguilar-Kirigin (2011) reported an extension in the altitudinal distribution of Bothrops sanctaecrucis based on the record of the specimen CBF 3359, which we identified in this study as belonging to the new species.

Adults of Bothrops monsignifer most probably feed on rodents. One of the dead individuals from Bolivia (MNK 5557) had traces of rodent hair in its feces. The adult female CORBIDI 10377 gave birth eighteen neonates (two dead and 16 live) on February 3, 2007 at the Instituto Nacional de Salud (INS, Lima, Peru).

Etymology. The specific epithet is derived from the Latin (noun) by the union of "mons" (=montane) + "ignifer" (=flame, fire or flash), meaning fire mountain or volcano, in allusion to the location where the first Bolivian specimen was photographed (Refugio Los Volcanes, department of Santa Cruz, Bolivia).
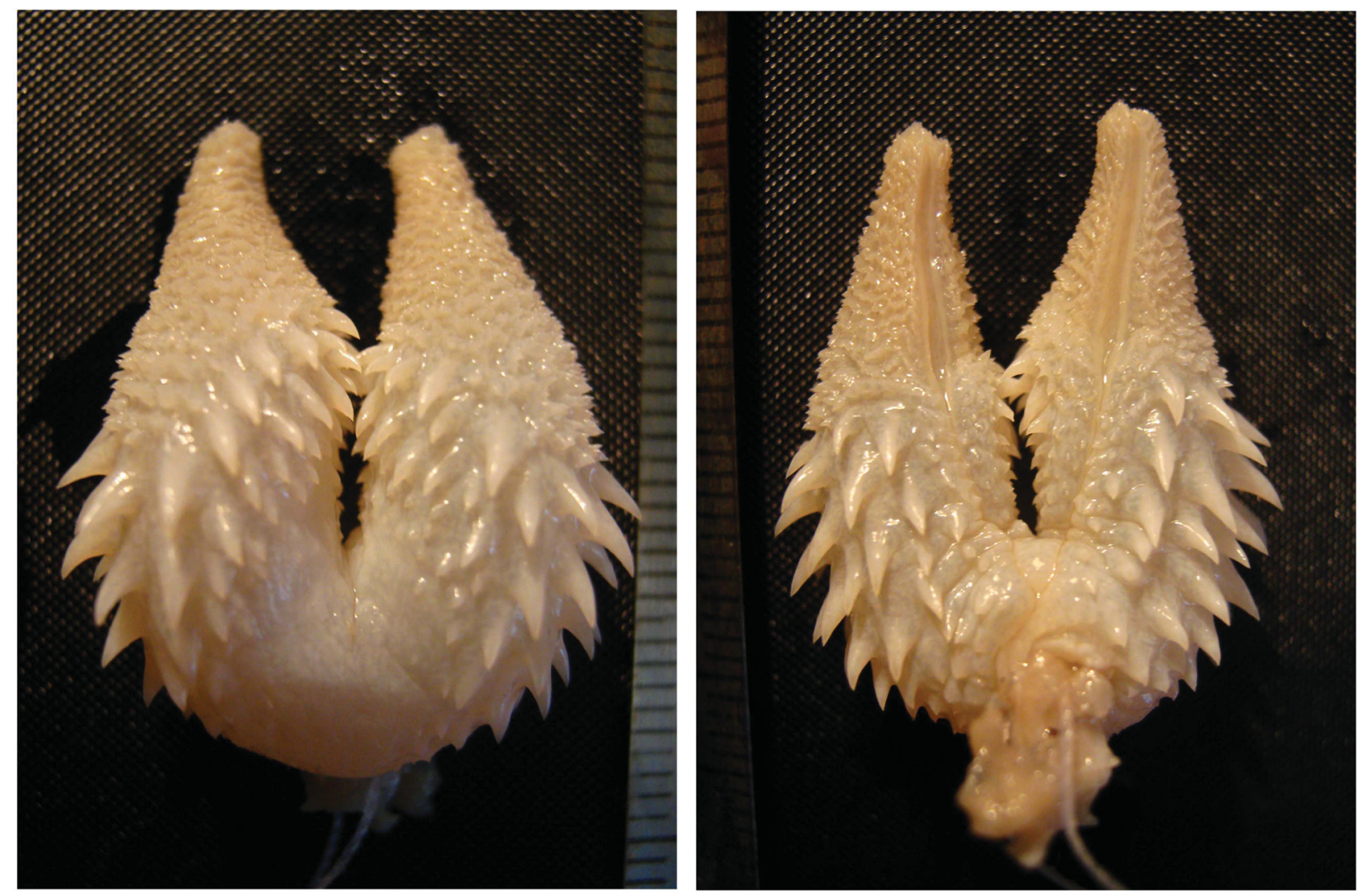

FIGURE 10. Asulcate (left) and sulcate (right) views of the hemipenis of the paratype of Bothrops monsignifer (MNK 4313, $\mathrm{TL}=26.87 \mathrm{~mm})$.

\section{Discussion}

Bothrops monsignifer seems to have gone unnoticed or been confused with other species of the genus in the past 
decades. Some individuals of Bothrops monsignifer, especially males, can be mistaken with B. mattogrossensis. In Bolivia, locals traditionally refer to the new species as "chuta", a local name for Bothrops mattogrossensis. It is important to note that, in the present study, we followed Silva \& Rodrigues (2008) and referred to Bolivian populations of the "Bothrops neuwiedi" species group as B. mattogrossensis, but this classification should be taken with caution. A recent study (Carrasco et al. 2019) found that those populations from Bolivia are morphologically similar and phylogenetically related to Bothrops diporus, hence a taxonomic re-arrangement may be required. The specimen pictured and illustrated as "Bothrops andianus" in Campbell \& Lamar (2004, p. 370), clearly fits the description and distribution of the new species. This specimen (AMNH 73626) was found in San Juan, department of Puno, Peru, at $2133 \mathrm{~m}$. The picture identified as Bothrops mattogrossensis on Plate 645 of Campbell \& Lamar (2004), a specimen kept in the Instituto Nacional de Salud (Lima, Peru), also fits the description of the new species; it was found in Sandia, department of Puno, Peru, at $1800 \mathrm{~m}$.

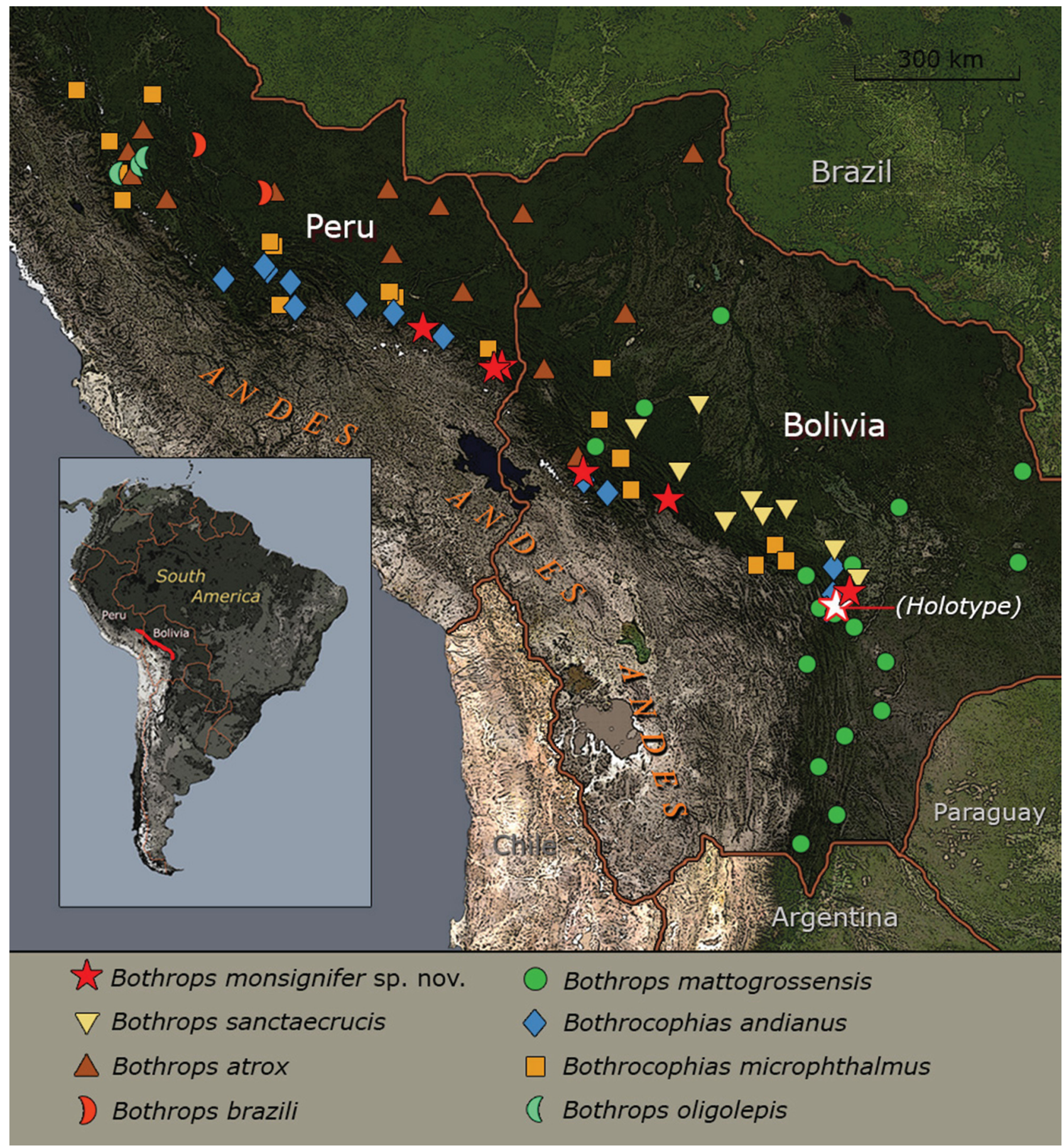

FIGURE 11. Distribution of Bothrops monsignifer and geographically close species of Bothrops and Bothrocophias (based on the specimens examined). 

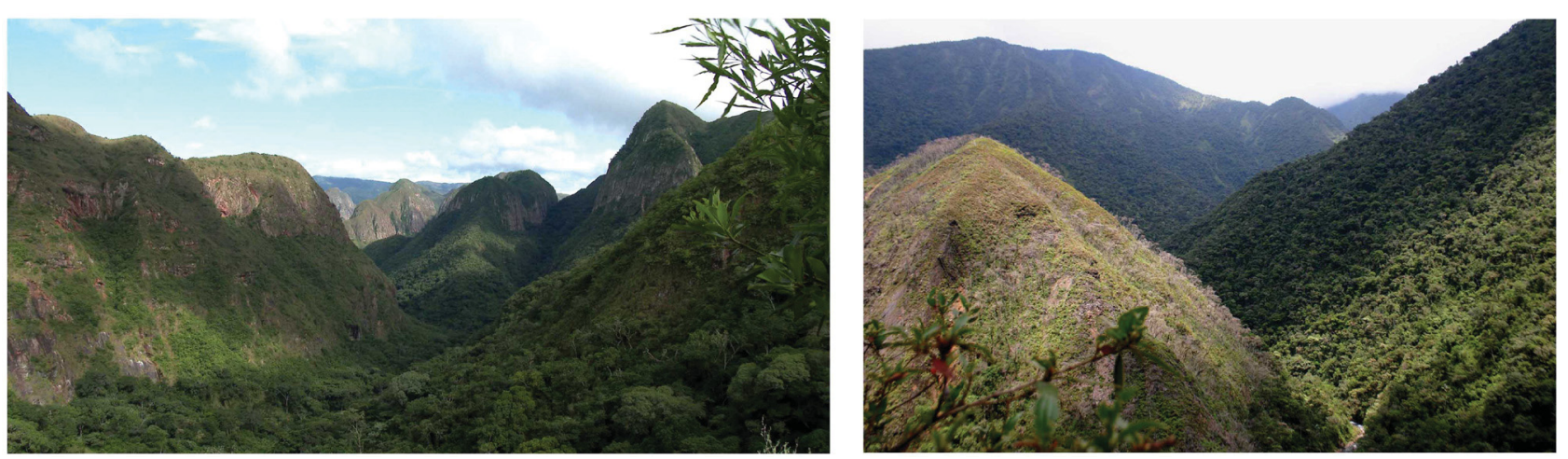

FIGURE 12. Landscape view of the habitat of Bothrops monsignifer at Refugio Los Volcanes, department of Santa Cruz, Bolivia (type locality_left; photo by J. Timms) and area between Chuine y Pacopacuni, department of Puno, Peru (right; photo by J.C. Chaparro (B).

The phylogenetic analyses confirmed the new species as a member of Bothrops, but did not fully resolve the position of the species within the genus. While total evidence analyses recovered Bothrops monsignifer as basal to the "B. jararaca" + "B. neuwiedi" clade, some of the partitioned analyses of the evidence showed a closer relationship of the new species to $B$. sanctaecrucis and related taxa from the "B. jararacussu" group. Apparently, the incongruences are due to different phylogenetic signals between the morphological and most of the molecular characters analyzed, which may reflect some homoplasy in either dataset. As mentioned before, Bothrops monsignifer may be easily distinguished from species of the "B. neuwiedi" group in several morphological characters from lepidosis and coloration. Bothrops monsignifer shares with species of the "B. jararaca" group the presence of a lacunolabial scale and the absence of subfoveals, important diagnostic features within Bothrops (Gutberlet \& Harvey 2004; Harvey et al. 2005; Carrasco et al. 2009, 2010), but they can be distinguished by other characters of lepidosis. Furthermore, while Bothrops monsignifer is an Andean species, the species of the " $B$. jararaca" group inhabit Atlantic forests and coastal islands in eastern Brazil. On the other hand, the relationship of Bothrops monsignifer with species of the "B. jararacussu" group is in accordance with morphological observations and comparisons. Whether the homoplasy is in molecular or morphological characters, this homoplasy represents an interesting evolutionary pattern to investigate more deeply. A similar situation regarding incongruent phylogenetic signal between morphological and molecular characters concern the phylogenetic relationship of the "Bothrops neuwiedi" and "B. jararaca" group with the rest of the groups of species of the genus. Previous total evidence and molecular analyses had recovered "Bothrops neuwiedi" and "B. jararaca" as sister groups of species (e.g., Wüster et al. 2002; Fenwick et al. 2009; Carrasco et al. 2012; Alencar et al. 2016), while morphological analyses had recovered "B. alternatus" as the sister group of "B. neuwiedi" and the "B. jararaca" group related with the rest of the groups of species (Werman 1992; Carrasco et al. 2012).

Bothrops monsignifer displays many characters of other medium to large sized Bothrops species and probably reaches a total length of around $150 \mathrm{~cm}$. Such large individuals are capable of injecting considerable amounts of venom in a single bite, hence the species should be considered dangerous and potentially life-threatening. However, the restricted distribution and apparent rarity of this species suggest that it is unlikely to be a serious threat to human populations. Only the local farmers and hunters who enter deep into the forest might be at risk, but so far there have been no bite reports attributable to this species.

The discovery of this new, large species of pitviper emphasizes the potential of topographically complex regions like the Andes to harbor hitherto hidden diversity of even relatively conspicuous animal species. Additional species of Bothrops and related pitvipers from the Central Andes probably remain to be described.

\section{Acknowledgments}

We thank all the local people at El Palmar, Cuevas who helped finding some of the snakes studied in the present work, their goodness and hospitality is unprecedented: C. Soliz Mancilla, I. Soliz Mancilla, C. Soliz Mancilla, C. Soliz Mancilla, F. Guzmán Soliz, M. Guzmán Soliz, E. Vargas Soliz, D. Sansuste Mérida, B. Sansuste González, 
C. González Rodríguez, I. Arancibia Solar, M. Pérez Mariscal, L. Lijerón Montenegro, C. Lijerón Montenegro, J. Franco Guzmán, D. Coca Ortiz, E. Ligerón Yepez and M. Rojas. We also thank V. Perezagua for being a great camera man in one of the field trips in Bolivia. JCC is grateful to A. Quiroz for sharing fieldwork in Puno Department, and to APECO and Koepcke scholarships for financing field work. PJV is indebted with M. Lundberg for sharing his photographs and specimens' data of Instituto Nacional de Salud. PAC is grateful to D. Rodríguez for generously sharing field data and photographs on one of the specimens of the type series that he collected. For allowing examinations of preserved specimens in Bolivian and Peruvian herpetological collections we thank J. Aparicio (CBF), A. Muñoz (MHNC), L. González (MNK), and J. C. Cusi (MUSM). We are grateful to P. Passos and W. Wüster for their useful comments and suggestions on the manuscript. We are indebted to the Willi Hennig Society for making the TNT program freely available (accessible at ww.lillo.org.ar/phylogeny/tnt/). This study was partially supported by the Programa de Cooperación Científico-Tecnológica entre el Consejo Nacional de Ciencia, Tecnología e Innovación Tecnológica de Perú (CONCYTEC-FONDECYT CS-031-2014) y el Ministerio de Ciencia, Tecnología e Innovación Productiva de Argentina (MINCYT PE/13/06), and by the Consejo Nacional de Investigaciones Científicas y Técnicas (CONICET-PIP 11220150100788), Argentina.

\section{References}

Alencar, L.R., Quental, T.B., Grazziotin, F.G., Alfaro, M.L., Martins, M., Venzon, M. \& Zaher, H. (2016) Diversification in vipers: phylogenetic relationships, time of divergence and shifts in speciation rates. Molecular Phylogenetics and Evolution, 105, 50-62. https://doi.org/10.1016/j.ympev.2016.07.029

Arévalo, E., Davis, S.K. \& Sites, W.J. (1994) Mitochondrial DNA sequence divergence and phylogenetic relationships among eight chromosome races of the Sceloporus grammicus complex (Phrynosomatidae) in Central Mexico. Systematic Biology, 43, 387-418. https://doi.org/10.1093/sysbio/43.3.387

Barbo, F.E., Grazziotin, F.G., Sazima, I., Martins, M. \& Sawaya, R. (2012) A new and threatened insular species of lancehead from Southeastern Brazil. Herpetologica, 68, 418-429. https://doi.org/10.1655/HERPETOLOGICA-D-12-00059.1

Barbo, F.E., Gasparini, J.L., Almeida, A.P., Zaher, H., Grazziotin, F., Gusmão, R.B., Ferrarini, J.M.G. \& Sawaya, R.J. (2016) Another new and threatened species of lancehead genus Bothrops (Serpentes, Viperidae) from Ilha dos Franceses, Southeastern Brazil. Zootaxa, 4097, 511-529. http://dx.doi.org/10.11646/zootaxa.4097.4.4

Brack, A. (1986) Las Ecoregiones del Perú. Boletín de Lima, 44, 57-70.

Campbell, J.A. \& Lamar, W.W. (2004) The Venomous Reptiles of the Western Hemisphere. Comstock Publishing Associates, Ithaca, $1032 \mathrm{pp}$.

Carrasco, P.A., Harvey, M.B. \& Muñoz-Saravia, A. (2009) The rare Andean pitviper Rhinocerophis jonathani (Serpentes: Viperidae: Crotalinae): redescription with comments on its systematics and biogeography. Zootaxa, 2283, 1-15.

Carrasco, P.A., Leynaud, G.C. \& Scrocchi, G.J. (2010) Redescription of the southernmost snake species Bothrops ammodytoides (Serpentes: Viperidae: Crotalinae). Amphibia Reptilia, 31, 323-338. https:// doi.org/10.1163/156853810791769491

Carrasco, P.A., Mattoni, C.I., Leynaud, G.C. \& Scrocchi, G.J. (2012) Morphology, phylogeny and taxonomy of Southamerican bothropoid pitvipers (Serpentes: Viperidae). Zoologica Scripta, 41, 109-124. https://doi.org/10.1111/j.1463-6409.2011.00511.x

Carrasco, P.A., Venegas, P.J., Chaparro, J.C. \& Scrocchi, G.J. (2016) Nomenclatural instability in the venomous snakes of the Bothrops complex: implications in toxinology and public health. Toxicon, 119, 122-128. https://dx.doi.org/10.1016/j.toxicon.2016.05.014

Carrasco, P.A., Grazziotin, F.G., Santa Cruz Farfán, R., Koch, C., Ochoa, J.A., Scrocchi, G.J., Leynaud, G.C. \& Chaparro, J.C. (2019) A new species of Bothrops (Serpentes: Viperidae: Crotalinae) from Pampas del Heath, southeastern Peru, with comments on the systematics of the Bothrops neuwiedi species group. Zootaxa, 4565 (3), 301-344. https://doi.org/10.11646/zootaxa.4565.3.1

Esqueda, L.F., La Marca, E. \& Bazó, S. (2005) Un nuevo colúbrido semifosorial del género Atractus (Dipsadinae) de la vertiente lacustre de los Andes de Venezuela. Herpetotropicos, 2(2), 87-93.

Fenwick, A.M., Gutberlet, R.L., Evans, J.A. \& Parkinson, C.L. (2009) Morphological and molecular evidence for phylogeny and classification of South American pitvipers, genera Bothrops, Bothriopsis, and Bothrocophias (Serpentes: Viperidae). Zoological Journal of the Linnean Society, 156, 617-640. https://doi.org/10.1111/j.1096-3642.2008.00495.x

Ferrarezzi, H. \& Freire, E.M.X. (2001) New species of Bothrops Wagler, 1824 from the Atlantic forest of northeastern Brazil (Serpen- 
tes, Viperidae, Crotalinae). Boletim do Museu Nacional, Nova Série, Zoologia, 440, 1-10.

França, F.O.S. \& Málaque, C.M.S. (2003) Acidente botropico. In: Cardoso, J.L.C., França, F.O.S., Fan, H.W., Málaque, C.M.S. \& Haddad, V. (Eds.), Animais Peçonhentos No Brasil. Biologia, Clínica e Terapêutica dos Acidentes. Sarvier, São Paulo, pp. 72-86.

Goloboff, P.A., Mattoni, C.I. \& Quinteros, S. (2006) Continuous characters analyzed as such. Cladistics, 22, 589-601. https://doi.org/10.1111/j.1096-0031.2006.00122.x

Goloboff, P.A., Carpenter, J.M., Arias, J.S. \& Miranda Esquivel, D.R. (2008) Weighting against homoplasy improves phylogenetic analysis of morphological data sets. Cladistics, 24, 1-16.

https://doi.org/10.1111/j.1096-0031.2008.00209.x

Goloboff, P.A. \& Catalano, S.A. (2016) TNT version 1.5, including a full implementation of phylogenetic morphometrics. Cladistics, 32(3), 221-238.

https://doi.org/10.1111/cla.12160

Gutberlet, R.L., Jr. \& Campbell, J.A. (2001) Generic recognition for a neglected lineage of South American pitvipers (Squamata: Viperidae: Crotalinae), with the description of a new species form the Colombian Chocó. American Museum Novitates, $3316,1-15$. https://doi.org/10.1206/0003-0082(2001)316<0001:GRFANL >2.0.CO;2

Gutberlet, R.L.Jr. \& Harvey, M.B. (2004). The evolution of New World venomous snakes. In: Campbell, J.A. \& Lamar, W.W. (Eds.), The Venomous Reptiles of the Western Hemisphere. Comstock Publishing Associates, Ithaca, 1032 pp.

Gutiérrez, J.M. (2009) Snakebite envenomation in Central America. In: Mackessy, S.P. (Ed.), Handbook of Venoms and Toxins of Reptiles. CRC Press, Boca Raton, pp. 491-507. https://doi.org/10.1201/9781420008661.ch24

Harvey, M.B. (1994) A new montane pitviper (Viperidae: Bothrops) from Cochabamba, Bolivia. Proceedings of the Biological Society of Washington, 107, 60-66.

Harvey, M.B. \& Muñoz, A. (2004) A new species of Tomodon (Serpentes: Colubridae) from high elevations in the Bolivian Andes. Herpetologica, 60 (3), 364-372. https://doi.org/10.1655/03-57

Harvey, M.B., Aparicio, J. \& Gonzales, L. (2005) Revision of the venomous snakes of Bolivia: Part II. The pitvipers (Serpentes: Viperidae). Annals of the Carnegie Museum, 74, 1-37. https://doi.org/10.2992/0097-4463(2005)74[1:ROTVSO]2.0.CO;2

Koch, C., Venegas, P., Santa Cruz, R. \& Böhme, W. (2018) Annotated checklist and key to the species of amphibians and reptiles inhabiting the northern Peruvian dry forest along the Andean valley of the Marañón River and its tributaries. Zootaxa, 4385 (1), $1-101$. https://doi.org/10.11646/zootaxa.4385.1.1

Kontak, D.J., Clark, A.H., Farrar, E., Archibald, D.A. \& Baadsgaard, H. (1990) Late Paleozoic-early Mesozoic magmatism in the Cordillera de Carabaya, Puno, southeastern Peru: Geochronology and petrochemistry. Journal of South American Earth Sciences, 3 (4), 213-230. https://doi.org/10.1016/0895-9811(90)90004-K

Miranda Calle, A.B. \& Aguilar-Kirigin, A.J. (2011) Bothrops sanctaecrucis Hoge 1966 (Squamata: Viperidae). Cuadernos de Herpetología, 25 (1), 29-31.

Mueller, R., Beck, S.G. \& Lara, R. (2002) Potential vegetation based on climate-data in the Bolivian Yungas-forests. Ecología en Bolivia, 37(2), 5-14.

Parkinson, C.L., Campbell, J.A. \& Chippindale, P.T. (2002) Multigene phylogenetic analysis of pitvipers, with comments on their biogeography. In: Schuett, G.W., Höggren, M., Douglas, M.E. \& Greene, H.W. (Eds.), Biology of the Vipers. Eagle Mountain Publishing, Utah, pp. 93-110.

Passos, P., Arredondo, J.C., Fernandes, R. \& Lynch, J.D. (2009) Three New Atractus (Serpentes: Dipsadidae) from the Andes of Colombia. Copeia, 3, 425-436. https://doi.org/10.1643/CH-08-063

Perger, R. \& Guerra, F. (2012) Two new tiger beetle (Coleoptera, Carabidae, Cicindelitae) species from the Tucuman-Bolivian forest in the National Tariquia Reserve, Bolivia. Zootaxa, 3434, 49-58. https://doi.org/10.11646/zootaxa.3434.1.3

Pesantes, O.S. (1989) Relacões entre Algumas Espécies do Gênero Bothrops pela Eletroforese do Plasma e Morfología do Hemipenis (Serpentes: Viperidae). Unpbl. MSc. Dissertation, Universidade Estadual Paulista Júlio de Mesquita Filho, Rio Claro, 85 pp.

Remuzgo, C., Álvarez, M.P., Lazo, F. \& Yarlequé, A. (2000) Caracterización parcial del veneno de la serpiente cascabel Peruana Crotalus durissus terrificus. Revista Peruana de Biología, 7 (1), 67-73. https://doi.org/10.15381/rpb.v7i1.6729

Rojas-Morales, J.A. (2012) Snakes of an urban-rural landscape in the central Andes of Colombia: species composition, distribution and natural history. Phyllomedusa, 11 (2), 135-154. https://doi.org/10.11606/issn.2316-9079.v11i2p135-154

Sabaj, M.H. (2016) Standard symbolic codes for institutional resource collections in herpetology and ichthyology: an Online Reference. Available from: http://www.asih.org/ (accessed on November 2018)

Silva, V.X. \& Rodrigues, M.T. (2008) Taxonomic revision of the Bothrops neuwiedi complex (Serpentes, Viperidae) with description of a new species. Phyllomedusa, 7, 45-90. https://doi.org/10.11606/issn.2316-9079.v7i1p45-90 
Uetz, P. \& Hošek, J. (2018) The Reptile Database. Available from: http://www.reptile-database.org (accessed on November 2018)

Warrell, D.A. (2004) Snakebites in Central and South America: epidemiology, clinical features, and clinical management. In: Campbell, J.A. \& Lamar, W.W. (Eds.), The Venomous Reptiles of the Western Hemisphere. Cornell University Press, Ithaca and London, pp. 709-761.

Werman, S.D. (1992) Phylogenetic relationships of Central and South American pitvipers of the genus Bothrops (sensu lato): cladistic analysis of biochemical and anatomical characters. In: Campbell, J.A. \& Brodie, E.D. (Eds.), Biology of the Pitvipers. Selva, Tyler, Texas, pp. 21-40.

Wüster, W., Salomão, M.G., Quijada-Mascareñas, J.A., Thorpe, R.S. \& BBBSP (2002) Origins and evolution of the South American pitvipers fauna: evidence from mitochondrial DNA sequence analysis. In: Schuett, G.W., Höggren, M., Douglas, M.E. \& Greene, H.W. (Eds.), Biology of the Vipers. Eagle Mountain Publishing, Utah, pp. 111-129.

\section{SUPPLEMENTARY MATERIAL}

APPENDIX 1. Additional specimens photographed.

APPENDIX 2. Specimens examined.

APPENDIX 3. Morphological characters used in the phylogenetic analysis.

APPENDIX 4. Morphological matrix.

APPENDIX 5. GenBank accession numbers for each taxon used in the phylogenetic analysis. 